\title{
Metamorphic history and geodynamic significance of the Early Cretaceous Sabzevar granulites (Sabzevar structural zone, NE Iran)
}

\author{
M. Nasrabady ${ }^{1}$, F. Rossetti ${ }^{2}$, T. Theye ${ }^{3}$, and G. Vignaroli ${ }^{2}$ \\ ${ }^{1}$ Department of Geology, Imam Khomeini International University, Qazvin, Iran \\ ${ }^{2}$ Dipartimento di Scienze Geologiche, Università Roma Tre, Roma, Italy \\ ${ }^{3}$ Institut für Mineralogie, Universität Stuttgart, Stuttgart, Germany \\ Received: 11 May 2011 - Published in Solid Earth Discuss.: 19 May 2011 \\ Revised: 26 September 2011 - Accepted: 26 September 2011 - Published: 11 November 2011
}

\begin{abstract}
The Iranian ophiolites are part of the vast orogenic suture zones that mark the Alpine-Himalayan convergence zone. Few petrological and geochronological data are available from these ophiolitic domains, hampering a full assessment of the timing and regimes of subduction zone metamorphism and orogenic construction in the region. This paper describes texture, geochemistry, and the pressuretemperature path of the Early Cretaceous mafic granulites that occur within the Tertiary Sabzevar ophiolitic suture zone of NE Iran. Whole rock geochemistry indicates that the Sabzevar granulites are likely derived from a MORB-type precursor. They are thus considered as remnants of a dismembered dynamo-thermal sole formed during subduction of a back-arc basin (proto-Sabzevar Ocean) formed in the upper-plate of the Neotethyan slab. The metamorphic history of the granulites suggests an anticlockwise pressuretemperature loop compatible with burial in a hot subduction zone, followed by cooling during exhumation. Transition from a nascent to a mature stage of oceanic subduction is the geodynamic scenario proposed to accomplish for the reconstructed thermobaric evolution. When framed with the regional scenario, results of this study point to diachronous and independent tectonic evolutions of the different ophiolitic domains of central Iran, for which a growing disparity in the timing of metamorphic equilibration and of pressuretemperature paths can be expected to emerge with further investigations.
\end{abstract}

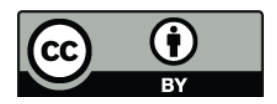

Correspondence to: F. Rossetti (rossetti@uniroma3.it)

\section{Introduction}

Ophiolitic suture zones are the remnants of the oceanic lithosphere consumed during orogenic construction and testify for oceanic closure during continental collision at the termination of a classical Wilson cycle (e.g. Wilson, 1966; Dewey and Bird, 1970; Cawood et al., 2009). The metamorphic record of the ocean-derived units marking orogenic suture zones provides key elements to decipher modes and regimes of oceanic subduction and to constrain paleotectonic reconstructions at (paleo-)convergent margins (e.g. Scambelluri et al., 1995; Peacock, 1996; Faccenna et al., 2001; Hacker et al, 2003; Jolivet et al., 2003; Brown, 2006, 2010; Bebout et al., 2007; Agard et al., 2009).

High-grade, granulite facies metamorphism is not commonly reported in modern (Phanerozoic) subduction zone settings, which are dominated by cold subduction of oceanic plates into the deep mantle (Hacker et al., 2003; Peacock et al., 1994; Stern, 2002; Brown, 2010). In these contexts, environments of formation of mafic high-pressure granulite suites in orogenic settings have been generally ascribed to two-end member processes: arc maturation, i.e. formation in consequence of magmatic loading at the mature arc stage (e.g. Garrido et al., 2006; Berger et al., 2009); or melting remnants of a former oceanic crust in high heat-flow oceanic subduction settings (Peacock et al., 1994; Liu et al., 1996; García Casco et al., 2007). The correct interpretation of the granulite-facies metamorphism in ophiolitic sutures is thus critical to understand both processes and history of oceanic subduction at convergent plate margins.

In this paper, we present new geochemical and petrological data on the Early Cretaceous migmatitic mafic granulites found within the Tertiary Sabzevar ophiolitic suture zone of

Published by Copernicus Publications on behalf of the European Geosciences Union. 

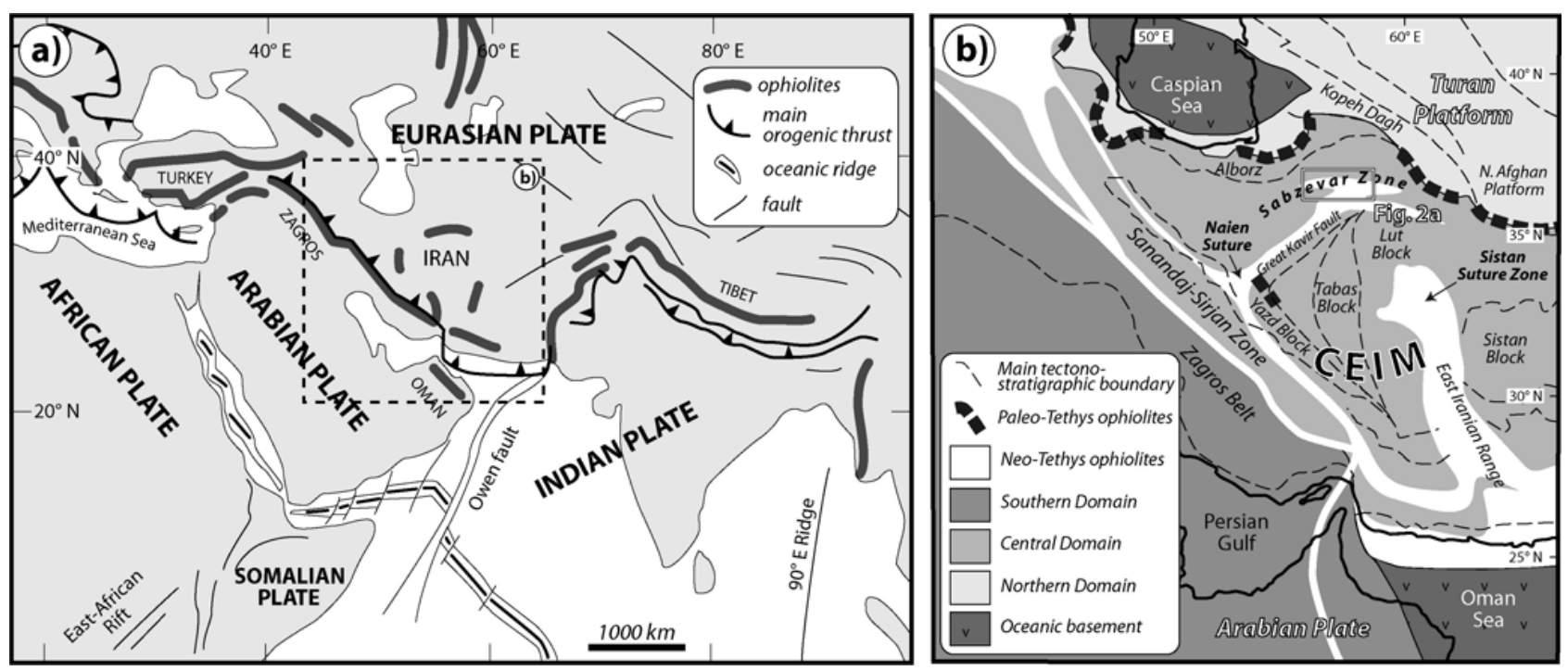

Fig. 1. (a) Distribution of the Tethyan ophiolitic suture zone along the Alpine-Himalayan convergence zone. (b) Simplified geological map showing the main tectonic domains in Iran, with the main (Neotethyan) ophiolitic belts (in white) indicated (modified after Shojaat et al., 2003; Bagheri and Stampfli, 2008). The rectangle indicates the study area. CEIM: Central East Iranian Microcontinent.

northeast Iran (Rossetti et al., 2010) (Fig. 1), and we describe their pressure-temperature $(P-T)$ history. These data are used to shed light on the $P-T$ regimes associated during closure of the ephemeral oceanic basins formed in the upperplate of the Neo-Tethyan subduction during the long-lasting Alpine convergence involving Eurasia and Arabia. Implications in terms of the regional geodynamics and orogenic complex evolution are also discussed.

\section{Geological background}

The remnants of the Tethyan oceanic realm running from the Mediterranean through East Europe, Middle East to Asia form the widest Tertiary orogenic suture zone in the Earth (Fig. 1a). These ophiolitic rocks record a polyphase and prolonged history of oceanic construction (the Paleozoic-Early Mesozoic Paleo-Tethys and the MesozoicCenozoic Neo-Tethys oceanic realms) and consumption during a sequence of Late Paleozoic to Cenozoic subduction/obduction/collision stages localized along the Eurasian active plate margin (e.g. Ricou, 1994; Besse et al., 1998; Dercourt et al., 2000; Stampfli and Borel, 2002; Golonka, 2004; Maheo et al., 2004; Agard et al., 2006; Zanchi et al., 2006; Bagheri and Stampfli, 2008). The Iranian ophiolites are an integral part of this evolving scenario, with the Neotethyan remnants distributed to mark diachronous closures of various oceanic branches during the Alpine-Himalayan convergence history (Takin, 1972; Stöcklin, 1974; Alavi-Tehrani, 1977; Sengör et al., 1988; McCall, 1997; Ghasemi and Talbot, 2006; Bagheri and Stampfli, 2008, and references therein).

The NW-SE trending ophiolitic belt of the Sabzevar Range is one of the Tertiary ophiolitic suture zones that surround the Central Iranian Microcontinent (CEIM; Figs. 1b and 2a). This ophiolitic domain is the remnant of one of the periTethyan oceanic branches (referred as the Sabzevar Ocean; Sengör et al., 1988; McCall, 1997; Bagheri and Stampfli, 2008) that bordered the northern margin of the CEIM toward the Asian Turan plate (Fig. 1b). It constitutes the largest ophiolitic massif ( $150 \mathrm{~km}$ long and $10-30 \mathrm{~km}$ wide) of north-eastern Iran and consists of a dismembered ophiolitic suite, with a tectonised and extensively serpentinised mantle section (harzburgite, dunite, and lherzolite) intruded by mafic magmas and a volcano-sedimentary sequence, Late Cretaceous to Paleocene in age (Alavi-Tehrani, 1977; Lensch et al., 1977; Delaloye and Desmons, 1980; Baroz et al., 1984; Shojaat et al., 2003). The geochemical signature of the ophiolitic rocks attests to a general MORB-like signature, suggesting that the oceanic lithosphere developed at an oceanic spreading centre (Baroz et al., 1984; Shojaat et al., 2003). These ophiolitic rocks dominantly occur dispersed as centimetre- to kilometre-size blocks into a highly sheared serpentinite matrix to form a major ophiolitic tectonic mélange. The blocks consist of serpentinised peridotites and intrusive and extrusive rocks, but foliated metabasites (blueschists, greenschists, and amphibolites) are also present. Syn-to-late tectonic, which are variably-sized granitic bodies, intrude the ophiolitic mélange, postdating main fabric development in the ophiolitic mélange and inducing contact metamorphism in the host rocks (Baroz et al., 1984). Another mélange unit underlies the tectonic mélange and consists of SE-verging imbricated thrust slices of red cherts and volcanic-volcaniclastic rocks, with features characteristic of a subduction-accretion complex (e.g. von Huene and Scholl, 1991) and form the frontal part of the range. The 

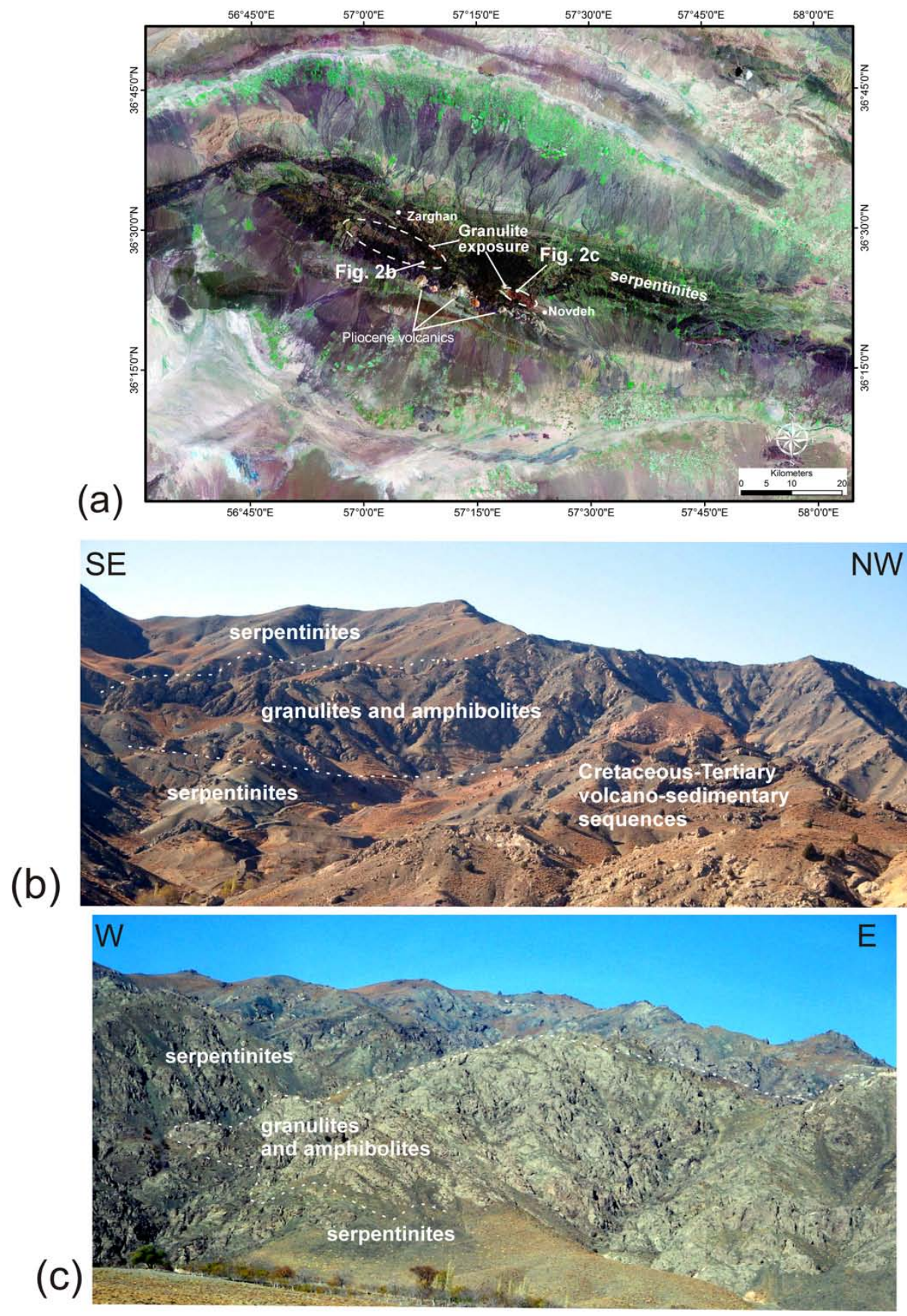

Fig. 2. (a) Satellite image of the Sabzevar Range and location of the granulite exposures (inset). (b) and (c) field exposures and characteristics of the granulite/serpentinite contacts. The granulites occur as massive bodies enclosed within the serpentinite mass.

timing of metamorphism in the Sabzevar structural zone has been constrained by $\mathrm{K}-\mathrm{Ar}$ muscovite and $\mathrm{Rb}-\mathrm{Sr}$ whole rock and mica geochronology. These data document that granitic magmatism occurred in the Early Eocene (at about $50 \mathrm{Ma}$ ), synchronous with the main greenschist-to-amphibolite retrograde metamorphism recorded in the metabasite blocks (Baroz et al., 1984).
Two exposures of km-scale mafic granulite bodies were recognised within the serpentinite mélange exposed in the NW portion of Sabzevar Range, to the north of the villages of Novdeh in the north and Zarghan in the south (Fig. 2a). Structurally, the granulite bodies occur as tectonic slivers embedded within the surrounding sheared serpentinite mélange (Fig. 2b-c). The field relationships with the mélange are usually obscured by intense fracturing and faulting related 


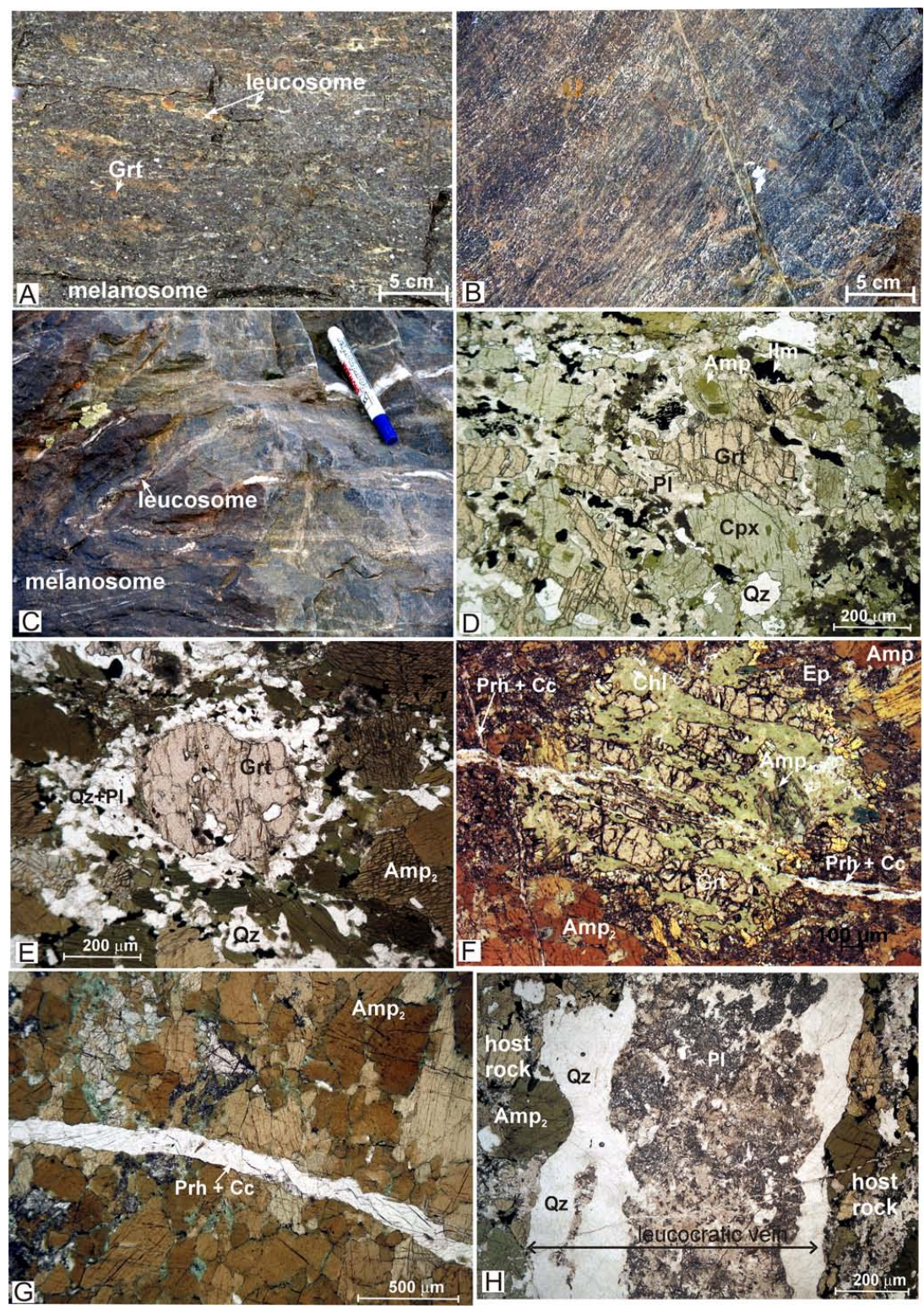

Fig. 3. (A)-(C) Granulite texture at the meso-scale. Note the presence of millimetric-to-centimetric leucocratic layers and patches that impart a stromatic texture to the rock. (D)-(E) Matrix assemblages at the thin section scale showing poikiloblastic garnet and clinopyroxene. Amphibole-plagioclase forms the main inclusion assemblage. Quartz-Plagioclase films surround garnet. (F) Porpyroclastic garnet surrounded by coronitic amphibole and late chlorite overgrowth. (G) Prehnite-calcite vein cutting across matrix amphibole. (H) Plagioclase alteration in leucosome.

to regional, post-orogenic strike-slip tectonics. The age of the peak granulite metamorphism was established through in situ $\mathrm{U}(-\mathrm{Th})-\mathrm{Pb}$ zircon and titanite geochronology, which point to an Early Cretaceous age (ca. 105 Ma) (Rossetti et al., 2010). This metamorphic age thus contrasts with the Late Cretaceous formation age of the Sabzevar ophiolites and the Tertiary age of their structuration (Baroz et al., 1984; Shojaat et al., 2003). Consequently, the Sabzevar granulites have to be considered as allocthonous tectonic slivers preserved within the Tertiary nappe edifice, and this evidence imposes re-consideration of the current tectonic models for the Alpine convergence history of the region.

\section{Granulite texture and petrography}

The granulite bodies are dark, medium to fine-grained rocks showing granoblastic groundmass or weak foliation (Fig. 3a). Their texture is dominated by the occurrence of millimetric-to-centimetric leucocratic patches and layers (leucosomes) interlayered within the mafic host rock 
Table 1. Location, texture, and mineral assemblages of the studied samples.

\begin{tabular}{|c|c|c|c|c|c|c|c|c|c|c|c|c|c|c|c|c|c|}
\hline Sample & Longitude (E) & Latitude $(\mathrm{N})$ & Texture & Rock type & $\mathrm{Am}_{1}$ & $\mathrm{Am}_{2}$ & $\mathrm{Am}_{3}$ & $\mathrm{Am}_{4}$ & $\mathrm{Cpx}$ & Grt & $\mathrm{Pl}$ & $\mathrm{Ilm}$ & $\mathrm{Rt}$ & Ttn & Chl & Prh & Zeo \\
\hline $\mathrm{Ng} 353$ & $57^{\circ} 21^{\prime} 19.7^{\prime \prime}$ & $36^{\circ} 11^{\prime} 48.3^{\prime \prime}$ & weak foliation & Leucosome-bearing & o & ++ & o & + & ++ & ++ & ++ & ++ & o & o & o & - & o \\
\hline $\mathrm{Ng} 421$ & $57^{\circ} 19^{\prime} 35.4^{\prime \prime}$ & $36^{\circ} 23^{\prime} 8.1^{\prime \prime}$ & $\begin{array}{l}\text { Cpx and Amph } \\
\text { layering }\end{array}$ & Leucosome-free & o & ++ & - & - & ++ & ++ & ++ & ++ & o & o & o & - & o \\
\hline Eg354d & $57^{\circ} 22^{\prime} 24.5^{\prime \prime}$ & $36^{\circ} 22^{\prime} 11.7^{\prime \prime}$ & weak foliation & Leucosome-free & o & ++ & ++ & ++ & ++ & ++ & + & + & o & o & + & + & + \\
\hline Sz290 & $57^{\circ} 08^{\prime} 52.4^{\prime \prime}$ & $36^{\circ} 28^{\prime} 11.4^{\prime \prime}$ & weak foliation & Leucosome-free & - & ++ & ++ & ++ & ++ & ++ & $\mathrm{o}$ & o & o & - & + & + & + \\
\hline $\mathrm{Ng} 360$ & $57^{\circ} 01^{\prime} 35.5^{\prime \prime}$ & $36^{\circ} 22^{\prime} 33.4^{\prime \prime}$ & weak foliation & Leucosome-bearing & o & ++ & o & - & ++ & ++ & ++ & + & o & o & o & - & - \\
\hline $\mathrm{Ng} 362$ & $57^{\circ} 20^{\prime} 33.2^{\prime \prime}$ & $36^{\circ} 22^{\prime} 53.9^{\prime \prime}$ & weak foliation & Leucosome-bearing & o & ++ & o & + & ++ & ++ & ++ & + & o & o & o & - & - \\
\hline $368 \mathrm{c}$ & $57^{\circ} 09^{\prime} 52.4^{\prime \prime}$ & $36^{\circ} 27^{\prime} 39.1^{\prime \prime}$ & decussate fabric & Leucosome-free & o & ++ & + & + & ++ & ++ & o & + & - & o & o & - & o \\
\hline Sz283 & $57^{\circ} 08^{\prime} 52.4^{\prime \prime}$ & $36^{\circ} 28^{\prime} 8.4^{\prime \prime}$ & $\begin{array}{l}\text { penetrative } \\
\text { foliation }\end{array}$ & Leucosome-free & - & ++ & - & - & - & - & ++ & o & - & - & o & o & o \\
\hline 272 & $57^{\circ} 09^{\prime} 14.3^{\prime \prime}$ & $36^{\circ} 28^{\prime} 28.1^{\prime \prime}$ & weak foliation & Leucosome-bearing & o & ++ & - & + & ++ & ++ & ++ & + & o & o & $\mathrm{o}$ & o & - \\
\hline $\mathrm{Ng} 351$ & $57^{\circ} 21^{\prime} 40.4^{\prime \prime}$ & $36^{\circ} 21^{\prime} 45.7^{\prime \prime}$ & decussate fabric & Leucosome-free & - & ++ & + & + & ++ & ++ & o & o & o & o & o & o & o \\
\hline Sz 403 & $57^{\circ} 08^{\prime} 05.2^{\prime \prime}$ & $36^{\circ} 28^{\prime} 1.3^{\prime \prime}$ & decussate fabric & Leucosome-free & o & ++ & - & o & - & + & o & + & - & - & - & - & - \\
\hline
\end{tabular}

++ major constituent; + minor constituent; o accessory phase; - not observed

mineral matrix (melanosome), giving the rock a migmatitic appearance (Fig. 3a-c). A list of the analysed samples, together with their geographic coordinates and mineralogical assemblages, are presented in Table 1. This study reports data on four granulite samples, selected from a representative regional sampling on the basis of: (i) preservation of the granulite facies assemblage and lack of pervasive amphibolite retrogression (sample NG353 and NG421); and (ii) evidence of retrograde amphibolite replacement (samples SZ290, EG354D). In the following sections, mineralogical abbreviations follow Whitney and Evans (2010).

\subsection{Host rock}

The mafic host rock makes up the bulk ( $>90 \%)$ of rocks and primarily define the main, coarse foliation in the outcrop and in the hand samples. The mineral assemblage mainly consists of amphibole + garnet + clinopyroxene with minor plagioclase \pm quartz. Rutile, titanite, ilmenite, zircon, and apatite occur as accessory minerals (see Table 1 for a synoptic view). The texture is granoblastic, with the exception of quartz and plagioclase that mostly occur as interstitial, curvilinear grains. Quartz also occurs as rounded inclusions in coarser grained matrix amphibole, garnet, and clinopyroxene. In samples NG353 and NG421, matrix garnets are medium-grained ( 1 to $5 \mathrm{~mm}$ ) porphyroblasts and are usually poikiloblastic, hosting clinopyroxene $\left(\mathrm{Cpx}_{1}\right)$, amphibole $\left(\mathrm{Amp}_{1}\right)$, plagioclase $\left(\mathrm{Pl}_{1}\right)$, quartz, rutile, ilmenite $\left(\operatorname{Ilm}_{1}\right)$, and titanite $\left(\mathrm{Ttn}_{1}\right)$ as inclusions (Figs. 3d-e and 4). In particular, $\mathrm{Amph}_{1}, \mathrm{Pl}_{1}, \mathrm{Ilm}_{1} / \mathrm{Ttn}_{1}$, and $\mathrm{Qz}$ form composite inclusions hosted at the garnet cores, whereas $\mathrm{Cpx}_{1}$ occurs in the rim regions (Fig. 4a-h). Particularly relevant for the metamorphic evolution of the Sabzevar granulites is the sequence in the Ti mineral phases with respect to garnet crystallization and matrix assemblages. The earliest Ti mineral record, preserved in garnet, is represented by titanite ${ }_{1}$, often preserved shielded in ilmenite ${ }_{1}$ or in equilibrium with ilmenite $_{1}$ (Fig. 4b, d, and g). Also mm-sized euhedral ilmenite-clinopyroxene-bearing pseudomorphs after titanite are often observed (Fig. 4d). The formation of $\mathrm{Ttn}_{1}$ predated the major garnet growth episode. This is also the case for a few single-phase $\mathrm{Ilm}_{1}$ inclusions in garnet and for the replacement of $\operatorname{Ttn}_{1}$ by $\mathrm{Ilm}_{1}$. Small single-phase Rt inclusions are abundant in garnet cores and rims (Fig. $4 \mathrm{c}$ and h). Accordingly, this mineral was stable during the main growth episode of garnet. As observed in some garnet grains, Rt crystallized at the expense of $\operatorname{Ilm}_{1}$ (Fig. 4c). In contrast, no $\mathrm{Rt}$ is present in the matrix. It exclusively survived as shielded inclusions in garnet or in some lager ilmenite grains. After or at the very end of the main garnet growth period, abundant $\mathrm{Ilm}_{2}$ crystallized in the matrix, partly directly at the expense of matrix Rt (Figs. 3d and 4i). Accordingly, the formation of Ti minerals can be chronologically grouped and related to major garnet growth: $\mathrm{Ttn}_{1} \rightarrow \mathrm{Ilm}_{1} \rightarrow \mathrm{Rt} \rightarrow \mathrm{Ilm}_{2}$. Both Ttn and $\mathrm{Ilm}_{1}$ predated garnet growth, Rt was stable during the major garnet growth period, and $\mathrm{Ilm}_{2}$ postdate garnet. A second generation of titanite $\left(\mathrm{Ttn}_{2}\right)$ occurs in the leucosome. In the heavily retrogressed samples, garnet is porphyroclastic, usually showing strong evidence for resorption with development of $\mathrm{Pl}+$ Amp symplectites and final break-down to form Chl-Ep-Amp composite association (Fig. 3f).

Clinopyroxene is usually found as main constituent of the matrix assemblage $\left(\mathrm{Cpx}_{2}\right)$. It consists of medium-tofine grains, which contain inclusions of ilmenite, plagioclase, quartz, and amphibole (Fig. 3d). Plagioclase is main constituent of the inclusion assemblage found in garnet and clinopyroxene $\left(\mathrm{Pl}_{1}\right)$, but also occurs as small, interstitial grains in matrix assemblages $\left(\mathrm{Pl}_{2}\right)$ (Fig. 3d). Four textural varieties of amphibole are identified: (i) amphibole inclusions within garnet and clinopyroxene $\left(\mathrm{Amp}_{1}\right)$ (Figs. $3 \mathrm{~d}$ and $4 \mathrm{~b}, \mathrm{e})$; (ii) coarse-grained matrix grains $\left(\mathrm{Amp}_{2}\right)$, with clear equilibrium textural relationships with garnet and clinpyroxene (Figs. 3d and 4h); (iii) symplectite- and coronatype amphibole $\left(\mathrm{Am}_{3}\right)$ intergrown with plagioclase and quartz around garnet grains and clinopyroxene (Fig. 3e); and (iv) pale green amphibole $\left(\mathrm{Amp}_{4}\right)$ crystallized after garnet 


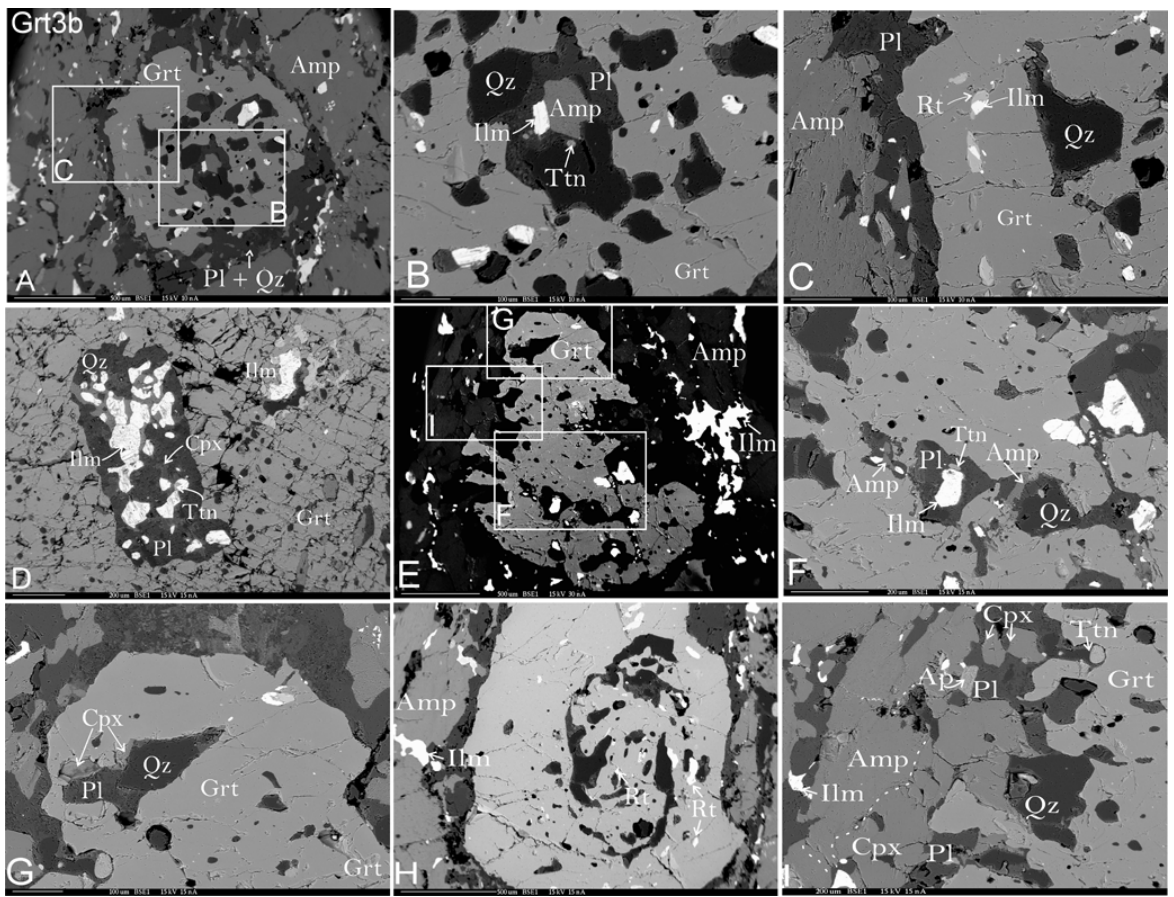

Fig. 4. Back-scattered electron images showing mineral and textural characteristics of the Sabzevar granulites (samples NG353 and NG421). (A)-(C) Poikiloblastic garnet with details on the core-rim distribution of the inclusion assemblages. The Ti-phases inclusions consist of ilmenite-titanite $\left(\operatorname{Ilm}_{1} / \mathrm{Ttn}_{1}\right)$ at the garnet core $(\mathbf{B})$ and of rutile that substitute ilmenite at the garnet rim (C). (D) Garnet core hosting ilmenite pseudomorphs after titanite. The inclusion assemblages also consists of clinopyroxene and plagioclase. (E) Large porphyroblastic garnet with details on the core-rim inclusion assemblages: amphibole occurs at the garnet core $(\mathbf{F})$, whereas clinopyroxene at the garnet rim $(\mathbf{G})$. Note that composite ilmenite-titanite ( $\left.\mathrm{Ilm}_{1}-\mathrm{Ttn}_{1}\right)$ assemblages occurs at the garnet core. (H) Rutile-bearing spiral trails of mineral inclusion in porphyroblastic garnet. Ilmenite occurs in the matrix assemblage $\left(\mathrm{Ilm}_{2}\right)$. (I) Poikyloblastic garnet and granular texture of the leucocratic quartz-plagioclase segregation. Titanite $\left(\mathrm{Ttn}_{2}\right)$ and ilmenite $\left(\mathrm{Ilm}_{2}\right)$ both occurs dispersed in the matrix assemblage.

breakdown (Fig. 3f). Texturally-late veins also occur, dominantly consisting of prehnite and albite with minor chlorite and epidote (Fig. 3g). In the heavily retrogressed samples, epidote forms pseudomorphous aggregates replacing garnet; while prehnite, albite, and chlorite appear in the matrix.

\subsection{Leucosome}

The leucosomes invariably consist of plagioclase + quartzrich continuous and concordant segregations of broadly tonalitic/trondhjemitic composition (modal proportions of quartz to plagioclase of 50-35/50-65). They show a systematic intragranular connectivity, with plagioclase and quartz showing a coarse granoblastic texture (Rossetti et al., 2010). Large xenomorphic (1-2 $\mathrm{mm}$ ) quartz grains also characterise many leucosomes, with these grains extending and dispersing outwards into the amphibole-rich host rock (Fig. 3h). Titanite $\left(\mathrm{Ttn}_{2}\right)$ is found in the leucosomes and is usually inclusion free. Plagioclase + quartz associations form filmlike intergrowth surrounding matrix amphibole. Evidence for solid-state deformation is limited, mostly attested by patchy undulose extinction in some quartz grains. In retrogressed samples, plagioclase is pseudomorphosed by prehnite-albite composite associations (Fig. 3h).

\section{Metamorphic evolution and reaction history}

The petrographic and textural features described above show that five main metamorphic stages $\left(\mathrm{M}_{1}\right.$ to $\left.\mathrm{M}_{5}\right)$ can be recognised in the Sabzevar ganulites (Table 2). This metamorphic evolution is primarily derived from the inclusion assemblages hosted in the garnet cores and clinopyroxene grains in samples NG353 and NG421, and by the reaction textures overprinting peak assemblages in samples SZ290 and EG354D.

The $M_{1}$ stage corresponds to the early prograde metamorphic history that is typified by the inclusion assemblage found in the garnet, i.e. it predates the main episode of garnet growth. The assemblage comprises $A m p_{1}+\mathrm{Pl}_{1}+\mathrm{Qz}+\mathrm{Ttn}_{1}+$ Ep. Probably formed in a later stage, $\operatorname{Ilm}_{1}$ is also enclosed in Grt, and $\mathrm{Ttn}_{1}$, completely pseudomorphed to $\mathrm{Ilm}_{1}+\mathrm{Cpx}+\mathrm{Qtz}$ (Fig. 4d). Replacement of $\mathrm{Ttn}_{1}$ could have been due to the prograde reaction (Frost et al., 2000):

$\mathrm{Amp}+\mathrm{Ttn}=\mathrm{Cpx}+\mathrm{Qtz}+\mathrm{Ilm}+\mathrm{H}_{2} \mathrm{O}$.

The $\mathrm{M}_{2 \mathrm{a}}$ stage corresponds to the main phase of garnet growth close to the metamorphic peak and to the crystallization of the matrix assemblage $\mathrm{Amp}_{2}+\mathrm{Pl}_{2}+\mathrm{Cpx}_{2} \pm \mathrm{Qtz}$. 
Table 2. Relations between metamorphic stage and mineral growth in the Sabzevar granulites.

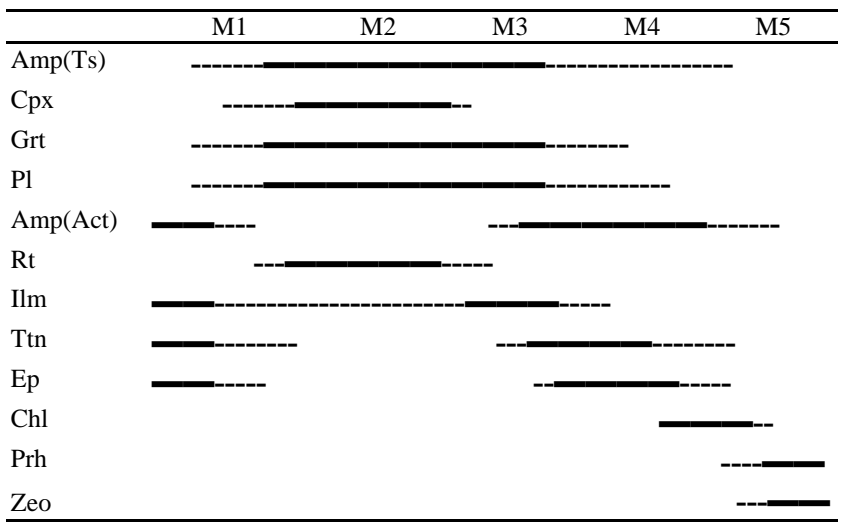

In particular, presence of rutile in spiral trails of inclusions in the garnet rims reflects the prograde history during garnet growth, likely after destabilisation of matrix $\operatorname{ttn}_{1}$ and $\mathrm{ilm}_{1}$. This assemblage can be then tentatively ascribed to a reaction such as (Manning and Bohlen, 1991; Tropper et al., 2002; Page et al., 2003):

$\mathrm{CzO}+\mathrm{Ttn}=\mathrm{Grs}+\mathrm{Rt}+\mathrm{Qz}+\mathrm{H}_{2} \mathrm{O}$.

After the main Grt growth episode, $\mathrm{Ilm}_{2}$ crystallized at the expense of rutile in the matrix in association with $\mathrm{Cpx}_{2}$, $\mathrm{Amph}_{2}$, Grt, and Plag $\left(\right.$ stage $\mathrm{M}_{2 \mathrm{~b}}$ ). This assemblage typifies the main equilibrium assemblage observed in fresh and unaltered granulite.

Crystallization of the granulitc garnet-clinopyroxeneamphibole matrix is associated with leucosome segregations. Leucosome textures such as those described in this study show striking similarities with those reported in Hartel and Pattison (1996), who interpreted the quartz + plagioclase leucosomes as melt textures produced by partial melting and hence product of migmatisation. In particular, the skeletal nature of the quartz and the plagioclase + quartz films argue for an internal origin of such melts (see Rossetti et al., 2010). Hence, the $\mathrm{M}_{2}$ stage involves amphibole dehydratation melting during prograde granulite facies migmatisation of a basic protolith according to the following generalised reaction (Hartel and Pattison, 1996):

$\mathrm{Amp}+\mathrm{Pl}=\mathrm{Grt}+\mathrm{Cpx}+\mathrm{Ttn}+$ trondhjemitic melt.

Accordingly, the metamorphic stage $\mathrm{M}_{2}$ is related to granulite formation associated with minor melt segregation.

$\mathrm{M}_{2}$ was followed by development of $\mathrm{M}_{3}$ symplectitic amphibole, plagioclase, quartz \pm ilmenite forming coronas around garnet and clinopyroxene associations. The observed reaction texture indicate garnet-consuming reaction such as (Mengel and Rivers, 1991; Willard and Adams, 1994; Zhao et al.; 2001)

$\mathrm{Grt}+\mathrm{Cpx}+\mathrm{Qz}+$ fluid $\rightarrow \mathrm{Amp}+\mathrm{Pl} \pm \mathrm{Mag}$.
Progress of this reaction needs fluid supply probably in response to external fluid infiltration during the uplift and related retrogressive evolution (Shervais et al., 2003; Engvik et al., 2007). Development of amphibole + plagioclase kelyphites around garnet have been observed in many granulite terranes and is generally related to a predominantly isothermal decompression after metamorphic peak (e.g. Harly, 1989; Carswell, 1990; Thost et al., 1991; O’Brien, 1997). In addition, growth of matrix ilmenite at the expense of rutile indicates retrogression of the HP assemblage according the bulk reaction (Zhao et al., 2001):

$\mathrm{Grt}+\mathrm{Rt} \rightarrow \mathrm{Ilm}+\mathrm{Pl}+\mathrm{Qz}$.

This reaction is mainly pressure-dependent and proceeds to the right with decompression (Liu et al., 1996; Liou et al., 1998).

Locally, a $\mathrm{M}_{4}$ metamorphic assemblage of $\mathrm{Amp}_{4}+\mathrm{Ep}$ \pm Chl statically grew. This assemblage formed at the expense of Grt, Cpx, and $\mathrm{Amph}_{1-2-3}$, indicating the following bulk reaction (Abbotto and Green Wood, 2001):

$$
\begin{aligned}
\mathrm{Cpx} & +\mathrm{Grt}+\mathrm{Amp}+\mathrm{Pl}+\text { fluid }+\mathrm{O}_{2} \rightarrow \mathrm{Amp}_{4} \\
& +\mathrm{Ep}+\mathrm{Chl}+\mathrm{Ab} .
\end{aligned}
$$

The latest stage of retrograde metamorphism is represented by the occurrence of $\mathrm{M}_{5}$ cross-cutting prehnite-bearing veins.

\section{Whole rock geochemistry}

Nine samples were geochemically analysed to constrain the paleo-tectonic setting on which their precursor rocks formed (see Table 1 for location and constituent mineralogy). Major and trace element abundances were obtained by inductively coupled plasma mass spectrometry (ICP-MS) at Activation Labs in Canada (analysis protocol 4E Research; method described in Hoffman, 1992; details can be found at http://www.actlabs.com/page.aspx?page=518\&app= $226 \&$ cat $1=549 \& \mathrm{tp}=12 \& 1 \mathrm{k}=$ no\&menu $=64 \&$ print $=$ yes $)$. The results are listed in Table 3 .

Major element analysis shows a restricted range of composition and a sub-alkaline, tholeiitic affinity. They have low silica (41-48 wt \% $\mathrm{SiO}_{2}$ ) and potassium (0.2-0.9 wt \% $\mathrm{K}_{2} \mathrm{O}$ ) contents with $\mathrm{Al}_{2} \mathrm{O}_{3}$ between 12.5 and $15.0 \mathrm{wt} \%$, for a \#Mg (molar $\left[\mathrm{MgO} / \mathrm{MgO}+\mathrm{Fe}_{\mathrm{Tot}}\right]$ ) of 38-65 (sample SZ290). In the TAS diagram, the studied granulite samples correspond to subalkaline, picro-basaltic to basaltic compositions (Fig. 5a). A determination of the protolith is considered to be tentative because it is difficult to assess the influence of interaction with metamorphic fluids as well as the amount of melt being extracted and removed from the rocks. A discrimination according to Irvine and Baragar (1971) and Winchester and Floyd (1976), classify the basaltic protolith as tholeiitic in composition (Fig. 5b-c). The rare earth element patterns are basically flat with a slight convex-upward distribution 
Table 3. Major and trace element composition of the Sabzevar granulite samples.

\begin{tabular}{|c|c|c|c|c|c|c|c|c|c|}
\hline Sample & NG 360 & NG 362 & NG 421 & SZ290 & $368 \mathrm{C}$ & SZ283 & EG354D & 272 & NG351 \\
\hline $\mathrm{SiO}_{2}$ & 48.22 & 47.22 & 45.99 & 43.63 & 41.25 & 48.85 & 48.07 & 47.58 & 41.85 \\
\hline $\mathrm{Al}_{2} \mathrm{O}_{3}$ & 12.71 & 12.55 & 12.92 & 14.44 & 15.00 & 14.50 & 12.37 & 12.85 & 14.28 \\
\hline $\mathrm{FeO}_{\mathrm{TOT}}$ & 16.17 & 15.28 & 15.53 & 9.14 & 15.08 & 11.56 & 17.11 & 16.50 & 15.07 \\
\hline $\mathrm{MnO}$ & 0.31 & 0.27 & 0.25 & 0.15 & 0.21 & 0.31 & 0.20 & 0.27 & 0.26 \\
\hline $\mathrm{MgO}$ & 7.05 & 7.59 & 6.51 & 10.81 & 12.69 & 8.80 & 7.29 & 6.53 & 10.49 \\
\hline $\mathrm{CaO}$ & 7.76 & 10.04 & 10.87 & 15.66 & 8.34 & 7.43 & 8.40 & 9.69 & 13.05 \\
\hline $\mathrm{Na}_{2} \mathrm{O}$ & 2.39 & 2.46 & 1.35 & 1.18 & 2.19 & 2.87 & 2.26 & 2.09 & 1.79 \\
\hline $\mathrm{K}_{2} \mathrm{O}$ & 0.68 & 0.58 & 0.87 & 0.19 & 0.37 & 1.08 & 0.68 & 0.73 & 0.30 \\
\hline $\mathrm{TiO}_{2}$ & 2.69 & 2.40 & 3.04 & 0.66 & 1.80 & 1.17 & 2.78 & 2.65 & 1.79 \\
\hline $\mathrm{P}_{2} \mathrm{O}_{5}$ & 0.27 & 0.26 & 0.28 & 0.07 & 0.11 & 0.06 & 0.31 & 0.26 & 0.20 \\
\hline LOI & 1.13 & 0.99 & 0.80 & 3.12 & 2.81 & 1.75 & 0.86 & 0.92 & 1.36 \\
\hline Total (wt \%) & 99.38 & 99.63 & 98.40 & 99.06 & 99.85 & 98.38 & 100.30 & 100.10 & 100.40 \\
\hline Sc (ppm) & 47 & 48 & 48 & 49 & 58 & 35 & 50 & 48 & 59 \\
\hline $\mathrm{V}$ & 506 & 480 & 529 & 224 & 382 & 260 & 511 & 507 & 374 \\
\hline $\mathrm{Sr}$ & 61 & 87 & 74 & 42 & 73 & 91 & 59 & 95 & 68 \\
\hline $\mathrm{Ba}$ & 26 & 17 & 52 & 12 & 20 & 107 & 13 & 37 & 9 \\
\hline $\mathrm{Cr}$ & 60 & 160 & 120 & 500 & 830 & 760 & 840 & 570 & 830 \\
\hline Co & 43 & 48 & 38 & 46 & 62 & 40 & 51 & 46 & 59 \\
\hline $\mathrm{Ni}$ & 40 & 80 & 60 & 130 & 370 & 360 & 460 & 310 & 370 \\
\hline $\mathrm{Cu}$ & 40 & 50 & 50 & $<10$ & 60 & 310 & 40 & 90 & 50 \\
\hline $\mathrm{Zn}$ & 120 & 40 & 130 & 80 & 160 & 500 & 150 & 140 & 120 \\
\hline $\mathrm{Ga}$ & 19 & 18 & 19 & 14 & 18 & 16 & 22 & 20 & 17 \\
\hline $\mathrm{Ge}$ & 2 & 2 & 2 & 1 & 2 & 2 & 2 & 2 & 2 \\
\hline As & $<5$ & $<5$ & $<5$ & $<5$ & $<5$ & $<5$ & $<5$ & $<5$ & $<5$ \\
\hline $\mathrm{Rb}$ & 8 & 5 & 13 & 1 & 4 & 21 & 6 & 14 & 1 \\
\hline $\mathrm{Y}$ & 57 & 48 & 61 & 18 & 35 & 26 & 58 & 56 & 39 \\
\hline $\mathrm{Zr}$ & 189 & 127 & 192 & 32 & 97 & 85 & 239 & 200 & 101 \\
\hline $\mathrm{Nb}$ & 5.7 & 5.4 & 5.9 & 2.5 & 9.1 & 2.6 & 6.5 & 5.1 & 6.6 \\
\hline $\mathrm{Cs}$ & 0.20 & 0.10 & 0.30 & $<0.1$ & 0.30 & 0.30 & 0.10 & 0.40 & $<0.1$ \\
\hline $\mathrm{La}$ & 7.94 & 10.70 & 9.16 & 3.04 & 3.44 & 4.38 & 10.50 & 7.72 & 9.17 \\
\hline $\mathrm{Ce}$ & 22.00 & 25.40 & 25.40 & 7.13 & 9.01 & 11.00 & 30.30 & 22.60 & 22.10 \\
\hline $\operatorname{Pr}$ & 3.53 & 4.23 & 3.96 & 1.05 & 1.49 & 1.69 & 4.91 & 3.73 & 3.27 \\
\hline $\mathrm{Nd}$ & 18.00 & 21.00 & 20.40 & 5.69 & 8.13 & 8.39 & 24.40 & 19.40 & 15.50 \\
\hline $\mathrm{Sm}$ & 6.06 & 6.91 & 6.81 & 1.90 & 3.30 & 2.87 & 8.14 & 6.47 & 4.88 \\
\hline $\mathrm{Eu}$ & 2.00 & 2.18 & 2.28 & 0.77 & 1.26 & 0.94 & 2.51 & 2.03 & 1.80 \\
\hline $\mathrm{Gd}$ & 6.44 & 8.54 & 7.26 & 2.46 & 4.66 & 3.84 & 9.88 & 8.45 & 6.02 \\
\hline $\mathrm{Tb}$ & 1.62 & 1.58 & 1.80 & 0.47 & 0.94 & 0.74 & 1.77 & 1.63 & 1.14 \\
\hline Dy & 9.94 & 9.15 & 11.00 & 3.00 & 6.01 & 4.58 & 10.70 & 10.00 & 6.94 \\
\hline Ho & 2.18 & 1.97 & 2.41 & 0.62 & 1.29 & 0.96 & 2.11 & 2.14 & 1.40 \\
\hline $\mathrm{Er}$ & 6.04 & 5.47 & 6.80 & 1.81 & 3.90 & 2.83 & 5.88 & 6.22 & 4.05 \\
\hline $\mathrm{Tm}$ & 0.99 & 0.86 & 1.11 & 0.26 & 0.61 & 0.44 & 0.86 & 0.95 & 0.62 \\
\hline $\mathrm{Yb}$ & 5.91 & 5.47 & 6.73 & 1.56 & 4.14 & 2.85 & 5.39 & 6.17 & 3.98 \\
\hline $\mathrm{Lu}$ & 0.87 & 0.78 & 0.97 & 0.22 & 0.70 & 0.45 & 0.85 & 1.00 & 0.63 \\
\hline $\mathrm{Hf}$ & 4.70 & 3.40 & 5.00 & 0.90 & 2.00 & 1.70 & 4.70 & 4.20 & 1.90 \\
\hline $\mathrm{Ta}$ & 0.48 & 0.39 & 0.50 & 0.15 & 0.59 & 0.18 & 0.44 & 0.38 & 0.46 \\
\hline W & 0.60 & $<0.5$ & $<0.5$ & $<0.5$ & 3.70 & 1.50 & 1.40 & 0.60 & 1.10 \\
\hline $\mathrm{Tl}$ & $<0.05$ & $<0.05$ & 0.08 & $<0.05$ & 0.07 & 0.13 & $<0.05$ & 0.12 & $<0.05$ \\
\hline $\mathrm{Pb}$ & $<5$ & $<5$ & $<5$ & 6.00 & $<5$ & $<5$ & $<5$ & $<5$ & $<5$ \\
\hline $\mathrm{Bi}$ & $<0.1$ & $<0.1$ & $<0.1$ & $<0.1$ & $<0.1$ & $<0.1$ & $<0.1$ & $<0.1$ & $<0.1$ \\
\hline $\mathrm{Th}$ & 0.41 & 0.83 & 0.47 & 0.19 & 0.45 & 0.47 & 0.66 & 0.52 & 0.69 \\
\hline $\mathrm{U}$ & 0.32 & 0.56 & 0.19 & 0.04 & 0.04 & 0.11 & 0.32 & 0.39 & 0.26 \\
\hline$(\mathrm{La} / \mathrm{Sm})_{N^{*}}$ & 0.85 & 1 & 0.87 & 1.03 & 0.73 & 0.65 & 0.95 & 0.81 & 0.75 \\
\hline
\end{tabular}

* Normalised values after CI chondrite values (Sun and McDonough, 1989). 

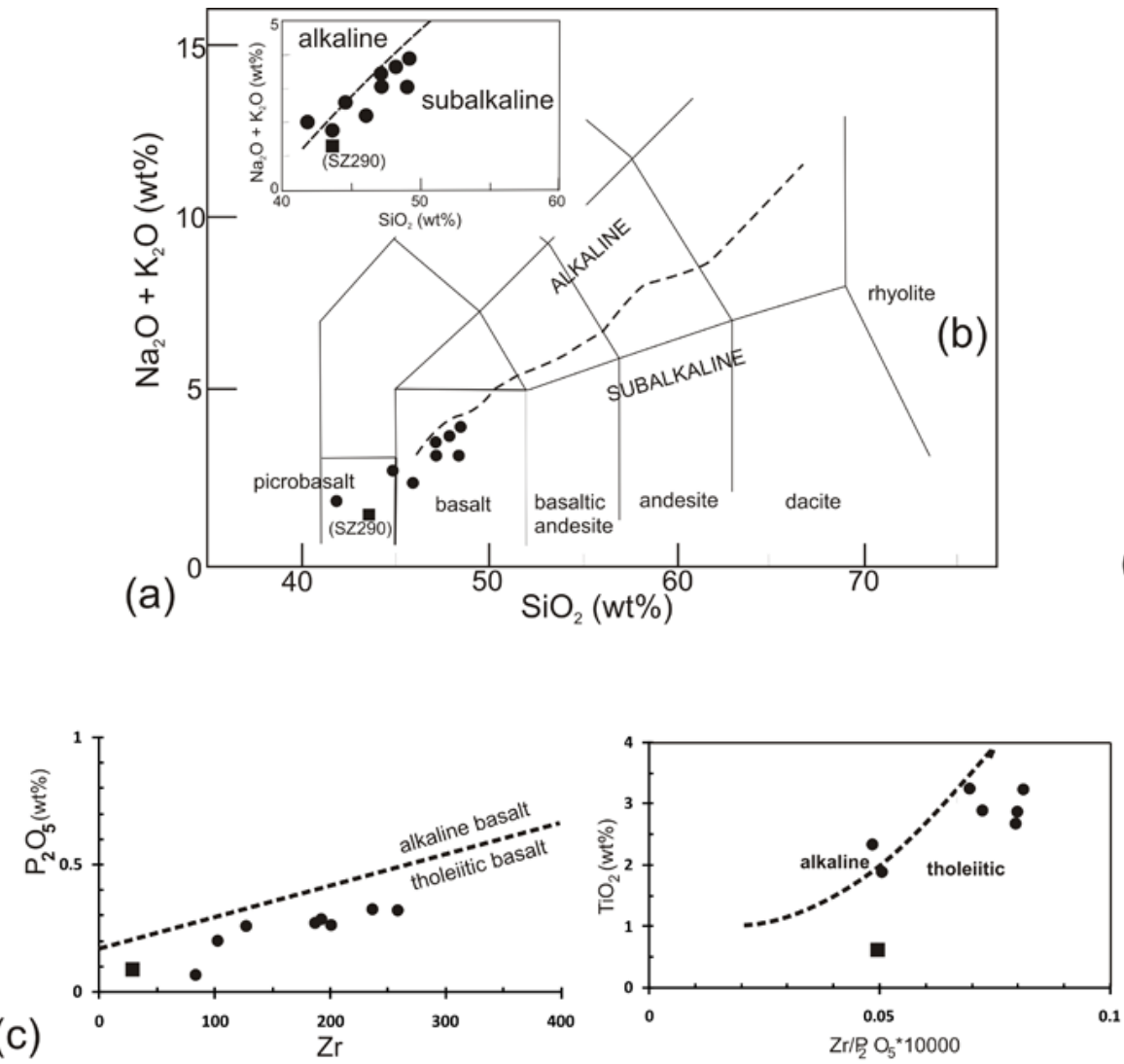

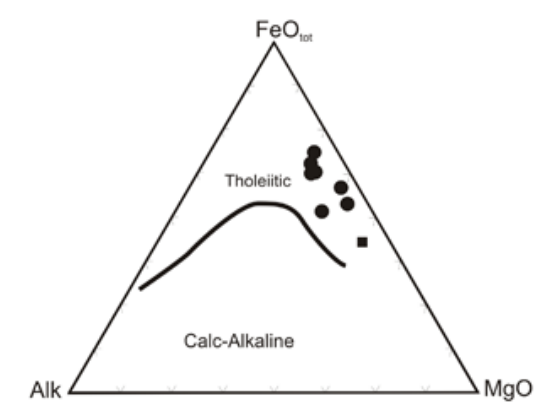

(b)

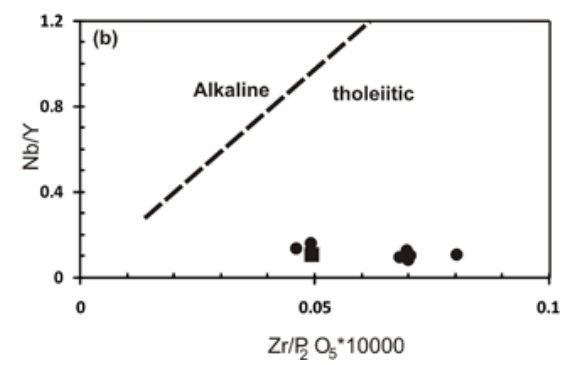

Fig. 5. Classification diagrams for the Sabzevar granulites. (a) Plot of total alkali vs. silica (Le Bas et al., 1992); (b) AFM diagram after Irivine and Baragar (1971); (c) after Winchester and Floyd (1976). Key to symbols: square is sample SZ290.

$\left([\mathrm{Gd} / \mathrm{Yb}]_{N}\right.$ 0.9-1.5) and no significant Eu anomaly. The $(\mathrm{La} / \mathrm{Sm})_{N}$ values are low (0.7-1.0) and their REE concentrations range between 10 and 50 times chondritic values (Fig. 6a). On a MORB-normalized diagram, the fluid-mobile LILE scatter widely, and element ratios based on them show little or no systematic behaviour indication some disturbance by interaction with metamorphic fluids. On the other hand, the fluid immobile trace elements show flat patterns compatible with a MORB signature (Fig. 6b). This interpretation is supported by $\mathrm{Nb} / \mathrm{La}$ values ranging between between 0.5 and 1.3. In a plot of $(\mathrm{La} / \mathrm{Sm})_{N}$ vs. $\mathrm{Nb} / \mathrm{La}$ (after John et al., 2003; not shown), the samples are far from the arc magmatism fields and fall in-between the back-arc and MORB ones. Values of $\mathrm{Th} / \mathrm{Yb}$ range between 0.07 and $0.16, \mathrm{Nb} / \mathrm{Yb}$ between 0.96 and 1.60; values strongly resembling those of average N-MORB (see Pearce, 2008). In a $\mathrm{Sr} / \mathrm{Y}$ vs. $(\mathrm{La} / \mathrm{Sm})_{N}$ diagram (after Berger et al., 2009), the granulites have a Sr/Y ratio significantly lower than in intra-oceanic arc lavas (exemplified by Caribbean Cretaceous lava); they plot close to the fields of MORB-type lavas (Fig. 7a). In geotectonic discrimination diagrams based on "immobile" elements for basaltic rocks, majority of the samples plot in the MORB/back-arc fields (Fig. 7b-c).
Although significantly disturbed, the evaluation of the observed signatures generally suggests MORB as protolith (cf. Arevalo Jr. and McDonough, 2010). The enrichment of incompatible trace elements could be attributed to their metamorphic evolution in consequence of interactions with enriched metamorphic fluids, melt segregation and extraction. In particular, a garnet-amphibole rich residual mineralogy during partial melting may produce the relatively high level of heavy REE (HREE) in the granulite restite (e.g. Rapp et al., 1991; Sen and Dunn, 1994; Martin et al., 2005). It is beyond the scope of the present paper to address the quantification of such processes on the geochemistry of the protolith. Basically, despite possible modification of the original major and trace element patterns caused by the metamorphic evolution,, the overall whole rock data of the Sabzevar granulites suggests a MORB-type/backarc oceanic protolith.

\section{Mineral chemistry}

The chemical compositions of minerals were determined using a CAMECA SX100 electron microprobe at the Institute für Mineralogie of Universität Stuttgart. Electron microprobe analyses (EMPA) were carried out in focused beam 


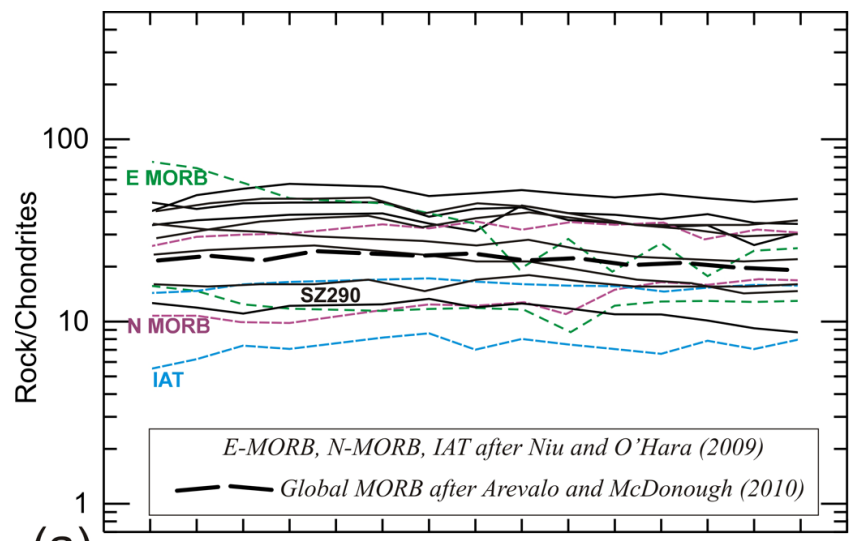

(a) La Ce Pr NdPmSm Eu Gd Tb Dy Ho Er Tm Yb Lu

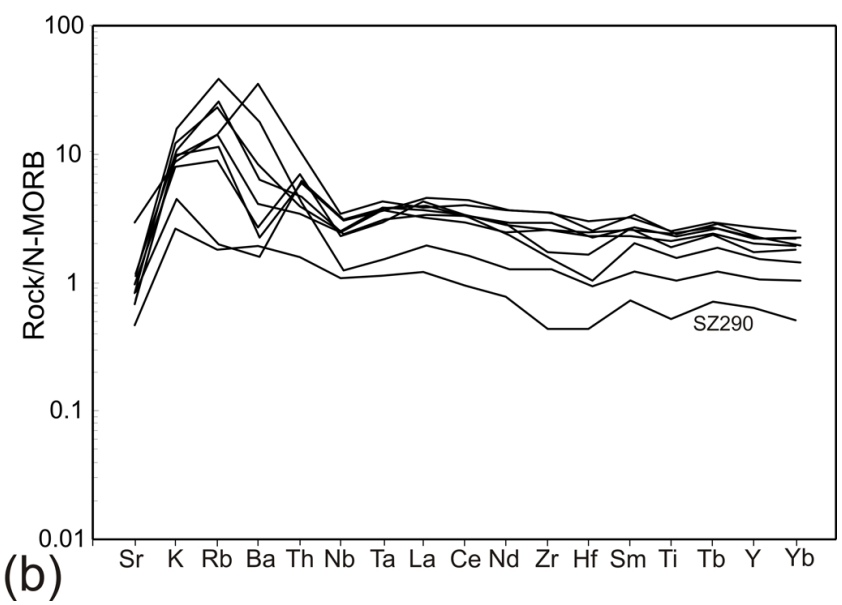

Fig. 6. Chondrite normalised REE patterns (a) and MORBnormalised trace element spider diagrams (b) for the Sabzevar granulites. Normalised values are after Sun and McDonough (1989).

mode at $15 \mathrm{kV}$ and $15 \mathrm{nA}$, using natural minerals and synthetic phases as standards. Concentration map for major elements $(\mathrm{Ca}, \mathrm{Fe}, \mathrm{Mg}, \mathrm{Mn}, \mathrm{Al}, \mathrm{Na})$ were also produced by stepwise movement of the thin section under the electron beam. Mineral recalculation and estimation of $\mathrm{Fe}^{3+}$ content were made using the AX2000 program in the THERMOCALCv.3.26 package (Powell and Holland, 2008; ftp: //www.esc.cam.ac.uk/pub/minp/thermocalc/). Selected mineral analyses and compositions are shown in Table 4.

\subsection{Garnet}

Representative garnet analyses are presented in Table 4a. Garnet composition is rather heterogeneous. It is essentially almandine $(38-52 \%)$, but it shows a large variation in grossular (26-34\%) and pyrope (12-30\%) components; spessartine (1-7\%) is present in minor amounts only (Fig. 8a). Representative compositional profiles and X-ray compositional maps are shown in Fig. 9. Three main types of chemical zoning are recognised (cf. Spear, 1993): (i) prograde zoning documented by a more or less pronounced (core-to-rim) bell shaped spessartine profile and pyrope increase (Fig. 9a); (ii) flat chemical profiles with retrograde zoning ( $\mathrm{Mg}$ decrease) in the rim regions (Fig. 9b); and (iii) composite patterns (Fig. 9c). In type (ii), a rimward increase of the grossular component is observed, largely compensated by a decrease of the pyrope content. In garnet with outlines pointing to major resoprtion, the rimward chemical zoning is also typified by an increase in XFe values in conjunction with spessartine increase. Flat chemical profiles are typified by the lower spessartine and higher pyrope contents. $\mathrm{Mg}$-rich garnet is generally related to temperature close to peak metamorphic conditions (e.g. Spear and Selverstone, 1983), being in line with the flat chemical profile (e.g. Spear, 1993; Ganguly, 2002). A similarly high Mg content occurs at the rim of the progradely zoned garnets that we thus attribute to the metamorphic peak. The sharp increase of the $\mathrm{Ca}$ and decrease of $\mathrm{Mg}$ contents with flat $\mathrm{Mn}$ and Fe contents can be explained as due to garnet growth in presence of a Ca-rich melt phase, i.e. during cooling (e.g. Spear and Kohn, 1996). The general picture described above is also complicated by ion diffusion next to both inclusions and external matrix minerals. For example, in garnets from sample SZ290, a 100$150 \mu \mathrm{m}$ wide zone with a sharp increase in $\mathrm{Mg}$ - and $\mathrm{Fe}$ - and depletion in Ca- and Mn-components is observed close to the clinopyroxene inclusions. Finally, various degrees of diffusion/resorption processes may have influenced the garnet zoning.

\subsection{Clinopyroxene}

Representative microprobe analyses and structural formula of clinopyroxene are reported in Table $4 \mathrm{~b}$. Their composition is dominated by the diopside component (49-60\%), with minor hedenbergite (10-30\%) and Ca-Tschermaks (2-18\%); Jadeite component is negligible $(<0.05)$ (Fig. 8b). Clinopyroxene occurring both in matrix and as inclusions in garnet shows similar composition. In all of the samples, a significant chemical zoning is observed from core to rim, which is typified by an increase of the $\mathrm{Ca}$ and $\mathrm{Mg}$ contents concomitantly with a decrease of the $\mathrm{Al}$ content (Fig. 9). A large variation in the Ca-Tschermaks component is also evident in the NG353 sample, in which clinopyroxene inclusions hosted in garnet contain lower $\mathrm{Al}$ and $\mathrm{Na}$, and higher $X_{\mathrm{Fe}}$ than the core of clinopyroxene dispersed in the matrix (Table $4 b$ ).

\subsection{Plagioclase}

Representative analyses are presented in Table 4c. Composition of plagioclase is distinctly different in the preserved and retrogressed rock types (Fig. 8c). In the first case (samples NG353 and NG421), all analysed plagioclase grains, regardless of their textural context (matrix, inclusions, leucosome), have andesine compositions $\left(\mathrm{An}_{43-51} \mathrm{Ab}_{50-56} \mathrm{Or}_{0-1}\right)$. In the second case, most of the plagioclase grains have been pseudomorphosed into an 

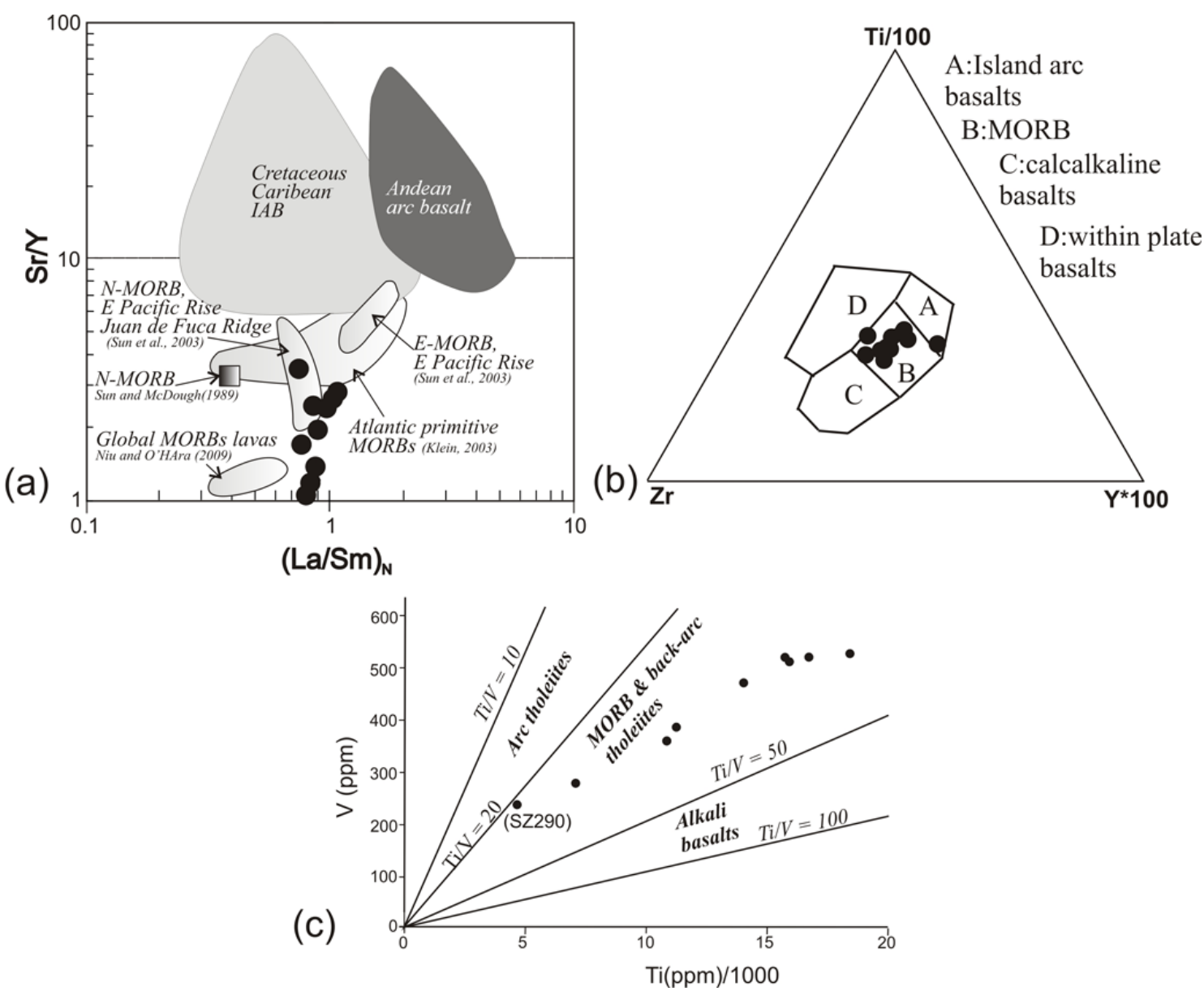

Fig. 7. Geotectonic discrimination diagrams for the Sabzevar granulites. (a) Sr/Y vs. $(\mathrm{La} / \mathrm{Sm})_{N}$ diagram (modified after Berger et al., 2009 and references therein). (b) After Pearce and Cann (1973); (c) after Shervais (1982).

albite-prehnite symplectite (sample SZ290). Albite also occurs as constituent of symplectite or in corona structures around garnet (sample EG354D). In several cases, matrix plagioclase shows alteration into prehnite.

\subsection{Amphibole}

Representative analyses of amphibole are given in Table $4 \mathrm{~d}$. In all samples, the composition of amphibole corresponds to tschermakite (Leake et al., 2004). In particular, amphibole from NG353 sample occurring in the matrix has the same composition as in the kelyphite structures around garnet and replacing clinopyroxene $\left[X_{\mathrm{Mg}}=\mathrm{Mg} /\left(\mathrm{Mg}+\mathrm{Fe}^{2+}\right)\right]$. On the other hand, coarse amphibole from sample SZ290 dispersed in the matrix shows higher $X_{\mathrm{Mg}}$ content (up to 0.88). Amphibole occurring as inclusion in garnet has been found in samples EG354D and NG353. It has a similar composition with respect to the ones found in matrix (just smaller $X_{\mathrm{Mg}}$ values). Late-stage, post-kinematic amphibole is actinolitic in composition (Fig. 8d).

\subsection{Epidote}

Epidote was found both as inclusions (sample NG353) in garnet and as constituent of the late retrogressive matrix assemblage. Matrix epidote is rich in pistacite $\left(\left[X_{\mathrm{Ps}}=\mathrm{Fe}^{3+} /\left(\mathrm{Fe}^{3+}+\mathrm{Al}\right)\right] \cdot 100\right.$; up to $\left.38 \%\right)$ with respect to epidote inclusion $\left(X_{\mathrm{Ps}}=5 \%\right)$.

\section{Thermobarometry}

To assess the $P-T$ evolution of the Sabzevar granulites, inverse and forward modelling techniques were integrated (cf. Powell and Holland, 2008). Inverse modelling combines conventional (single-reaction) thermobarometry with multi-equilibrium thermobarometry applying the THERMOCALC software (3.26 version) and its internally-consistent thermodynamic data set (Holland and Powell, 1998; Powell and Holland, 2008). Conventional thermobarometry includes Grt-Cpx-Pl-Qz (GADS barometry; Newton and Perkins, 1982; Eckert et al., 1991) and Grt-Amp-Pl-Qz (Kohn and Spear, 1990) barometry for pressure estimates; as well as the 
Table 4a. Representative EMPA analyses of garnet.

\begin{tabular}{|c|c|c|c|c|c|c|c|c|c|c|}
\hline \multirow{2}{*}{$\begin{array}{l}\text { Sample } \\
\text { Analysis }\end{array}$} & \multicolumn{4}{|c|}{ NG353 } & \multicolumn{2}{|c|}{ EG354 } & \multicolumn{2}{|c|}{ SZ290 } & \multicolumn{2}{|c|}{ NG421 } \\
\hline & \#48-c & \#43-r & \#36-c & \#42-r & $\# 24-\mathrm{c}$ & $\# 10-\mathrm{r}$ & \#6-c & \#13-r & 70 & 130 \\
\hline $\mathrm{SiO}_{2}$ & 37.67 & 37.46 & 37.55 & 37.47 & 37.90 & 37.65 & 38.55 & 38.59 & 39.01 & 37.64 \\
\hline $\mathrm{TiO}_{2}$ & 0.12 & 0.17 & 0.12 & 0.20 & 0.17 & 0.18 & 0.15 & 0.10 & 0.10 & 0.11 \\
\hline $\mathrm{Al}_{2} \mathrm{O}_{3}$ & 22.09 & 22.00 & 21.99 & 21.51 & 21.46 & 21.47 & 21.71 & 21.73 & 21.42 & 20.78 \\
\hline $\mathrm{Cr}_{2} \mathrm{O}_{3}$ & 0.03 & bdl & 0.01 & 0.01 & 0.02 & bdl & 0.08 & 0.02 & bdl & bdl \\
\hline $\mathrm{Fe}_{2} \mathrm{O}_{3}$ & 2.16 & 2.41 & 2.84 & 2.38 & 1.49 & 2.01 & 2.73 & 2.66 & 0.00 & 2.71 \\
\hline $\mathrm{FeO}$ & 23.53 & 23.04 & 23.26 & 22.97 & 22.76 & 22.77 & 17.89 & 20.15 & 25.20 & 23.54 \\
\hline $\mathrm{MnO}$ & 1.66 & 1.57 & 2.12 & 1.98 & 2.59 & 2.45 & 0.77 & 0.90 & 1.93 & 1.11 \\
\hline $\mathrm{MgO}$ & 4.54 & 3.89 & 4.74 & 3.71 & 3.13 & 3.06 & 7.47 & 7.91 & 3.96 & 4.07 \\
\hline $\mathrm{CaO}$ & 9.21 & 10.35 & 8.56 & 10.38 & 11.16 & 11.11 & 11.05 & 8.57 & 8.37 & 10.28 \\
\hline $\mathrm{Na}_{2} \mathrm{O}$ & 0.01 & 0.02 & 0.04 & 0.02 & 0.04 & 0.04 & 0.02 & 0.02 & bdl & bdl \\
\hline $\mathrm{K}_{2} \mathrm{O}$ & bdl & 0.01 & bdl & bdl & 0.01 & 0.02 & bdl & bdl & bdl & bdl \\
\hline Totals & 100.81 & 100.68 & 100.95 & 100.40 & 100.58 & 100.55 & 100.14 & 100.39 & 99.99 & 100.24 \\
\hline Oxygens & 12 & 12 & 12 & 12 & 12 & 12 & 12 & 12 & 12 & 12 \\
\hline $\mathrm{Si}$ & 2.92 & 2.91 & 2.91 & 2.93 & 2.96 & 2.95 & 2.94 & 2.94 & 3.05 & 2.95 \\
\hline $\mathrm{Ti}$ & 0.01 & 0.01 & 0.01 & 0.01 & 0.01 & 0.01 & 0.01 & 0.01 & 0.01 & 0.01 \\
\hline $\mathrm{Al}$ & 2.02 & 2.02 & 2.01 & 1.98 & 1.98 & 1.98 & 1.95 & 1.95 & 1.97 & 1.92 \\
\hline $\mathrm{Cr}$ & 0.00 & 0.00 & 0.00 & 0.00 & 0.00 & 0.00 & 0.01 & 0.00 & 0.00 & 0.00 \\
\hline $\mathrm{Fe}_{3}$ & 0.13 & 0.14 & 0.17 & 0.14 & 0.09 & 0.12 & 0.16 & 0.15 & 0.00 & 1.60 \\
\hline $\mathrm{Fe}_{2}$ & 1.53 & 1.50 & 1.51 & 1.50 & 1.49 & 1.49 & 1.14 & 1.29 & 1.65 & 1.55 \\
\hline $\mathrm{Mn}$ & 0.11 & 0.10 & 0.14 & 0.13 & 0.17 & 0.16 & 0.05 & 0.06 & 0.13 & 0.07 \\
\hline $\mathrm{Mg}$ & 0.53 & 0.45 & 0.55 & 0.43 & 0.36 & 0.36 & 0.85 & 0.90 & 0.46 & 0.48 \\
\hline $\mathrm{Ca}$ & 0.77 & 0.86 & 0.71 & 0.87 & 0.93 & 0.93 & 0.90 & 0.70 & 0.70 & 0.86 \\
\hline $\mathrm{Na}$ & 0.00 & 0.00 & 0.01 & 0.00 & 0.01 & 0.01 & 0.00 & 0.00 & 0.00 & 0.00 \\
\hline K & 0.00 & 0.00 & 0.00 & 0.00 & 0.00 & 0.00 & 0.00 & 0.00 & 0.00 & 0.00 \\
\hline Alm & 0.52 & 0.51 & 0.52 & 0.51 & 0.50 & 0.51 & 0.39 & 0.44 & 0.56 & 0.52 \\
\hline Grs & 0.26 & 0.30 & 0.24 & 0.30 & 0.32 & 0.32 & 0.31 & 0.24 & 0.24 & 0.29 \\
\hline Prp & 0.18 & 0.15 & 0.19 & 0.15 & 0.12 & 0.12 & 0.29 & 0.31 & 0.16 & 0.16 \\
\hline Sps & 0.04 & 0.04 & 0.05 & 0.04 & 0.06 & 0.06 & 0.02 & 0.02 & 0.04 & 0.02 \\
\hline
\end{tabular}

Mineral formula and ferric iron recalculation obtained through the software AX2000, enclosed in the THERMOCALC Package.

bdl, below detection limit; c, core; r, rim

Mg-Fe exchange for the both the Grt-Cpx (Ellis and Green, 1979; Krogh Ravna, 2000a) and Grt-Amp (Krogh Ravna, 2000b) pairs, and the Zr-in rutile (Zack et al., 2004; Watson et al., 2006; Ferry and Watson, 2007; Tomkins et al., 2007) thermometry for temperature estimates. When using the $\mathrm{Zr}$-in rutile thermometry (see below), calibrations by Watson et al. (2006), Ferry and Watson (2007) and Tomkins et al. (2007) gave similar results, whereas results from Zack et al. (2004) were systematically $100^{\circ} \mathrm{C}$ higher, and were not taken into account in this study. Both phase diagram and the average $P$ - $T$ THERMOCALC calculations mode have been applied, considering mineral data activities calculated by the AX program in the THERMOCALC package. For average pressure and temperature estimates, we only considered calculations showing a statistical consistency as expressed by the "sigfi" coefficient (Powell and Holland, 1994). A summary of the obtained results are shown in Table 5.
The $P-T-X$ (forward) modelling of the Sabzevar granulites during the $\mathrm{M}_{1}$-to- $\mathrm{M}_{2}$ composite metamorphic evolution was computed using the Perple_X_07 software (Connolly, 2005; http://www.perplex.ethz.ch, v. 6.6.5, downloaded 7 January 2011). Because of the unknown amount of melt extracted from the rock, the calculation is considered as tentative and, accordingly, results on $P-T$ conditions as semi-quantitative.

\subsection{Inverse modelling}

\subsection{1 $M_{1}$ stage}

For this early metamorphic stage, characterized by the assemblage Amp, Ep, Grt Ttn, lower amphibolite facies conditions can be assumed. 
Table 4b. Representative EMPA analyses of Clinopyroxene.

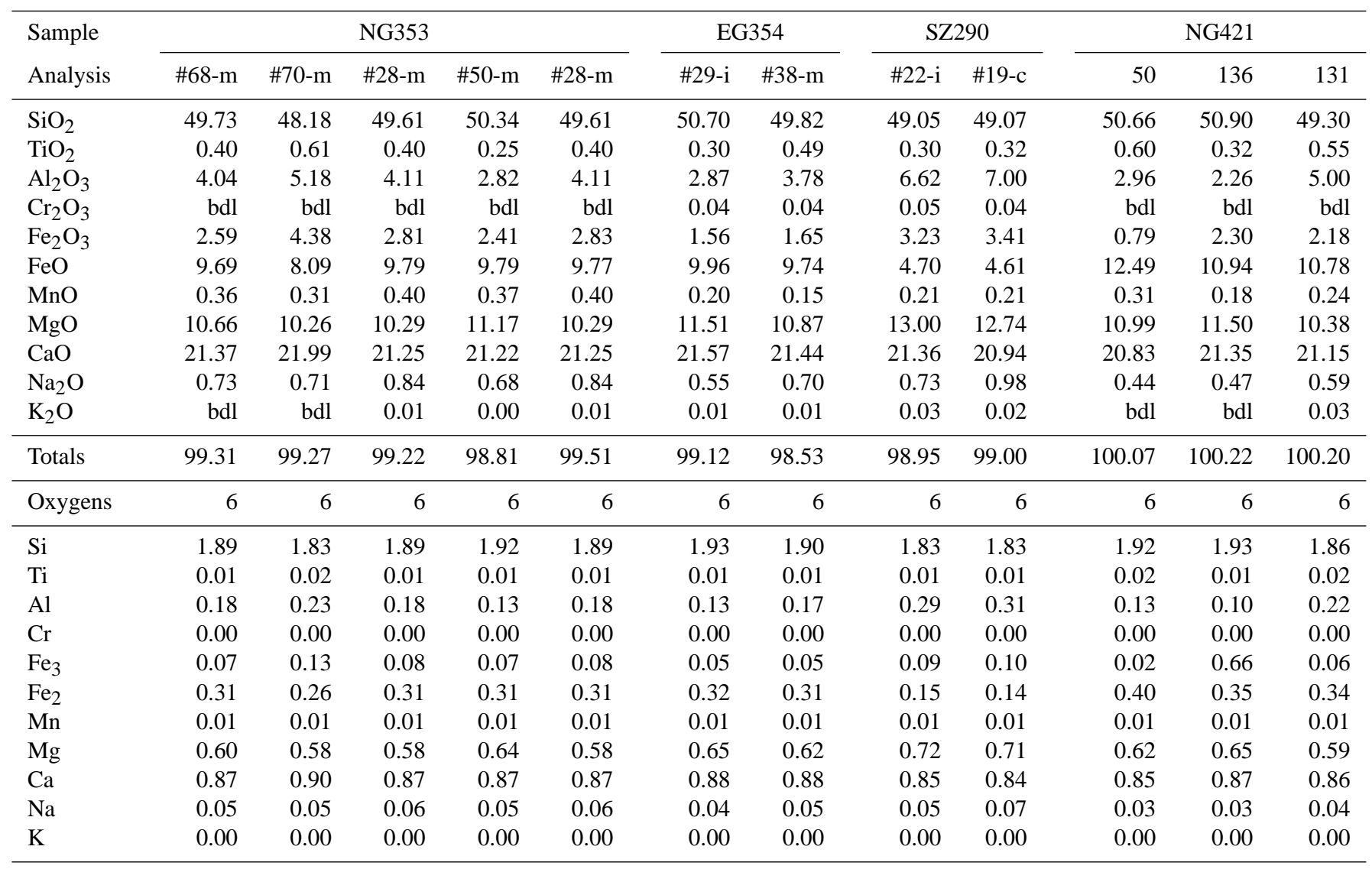

Mineral formula and ferric iron recalculation obtained through the software AX2000, enclosed in the THERMOCALC Package.

bdl, below detection limit; c, core; i, inclusion; $m$, matrix

\subsection{2 $\mathrm{M}_{2 \mathrm{a}}$ stage}

Prograde conditions were calculated using the composition of $\mathrm{Amp}_{1}+\mathrm{Pl}_{1}+\mathrm{Ilm}_{1}+\mathrm{Ttn}_{1}(+\mathrm{Qz})$ inclusion assemblages hosted within the core domain of the garnet. Average THERMOCALC $P-T$ estimates span for sample NG353 are $644 \pm 117^{\circ} \mathrm{C}, 0.8 \pm 0.1 \mathrm{GPa}$. For the same assemblages, the amphibole-garnet thermometry of Krogh Ravna (2000b) gives $640-750^{\circ} \mathrm{C}$.

\subsection{3 $\mathrm{M}_{2 b}$ stage}

The progressive transition to the $\mathrm{M}_{2 b}$ stage is related to growth of garnet in association with rutile. Peak conditions were calculated using the composition of (i) $\mathrm{Cpx}+\mathrm{Pl}+\mathrm{Rt} \pm \mathrm{Ilm}(+\mathrm{Qz})$ inclusions within the rim domain of the garnet and (ii) Grt-Cpx-Pl-Amp matrix assemblages showing textural equilibrium. The average $P-T$ calculations, as obtained with THERMOCALC, cluster around 750-850 ${ }^{\circ} \mathrm{C}$ and 1.0-1.2 GPa. A significantly lower temperature but similar pressure is calculated using the outer, $\mathrm{Ca}$ - rich garnet domains (Fig. 10). The Grt-Cpx thermometry of Krogh Ravna (2000a) and Ellis and Green (1979) (calculated for an average $P=1.0 \mathrm{GPa}$ for all samples) gave similar results, in the order of $715-765^{\circ} \mathrm{C}$. Using the composition of clinopyroxene with highest $\mathrm{Al}$ contents (in the rims) for the assemblage indicated above, calculated conditions are about $50-100^{\circ} \mathrm{C}$ higher, suggesting that peak $T$ was higher than obtained by the applied thermometers due to postpeak re-equilibration of clinopyroxene. The GADS barometry of Perkins and Newton (1981) and Eckert et al. (1991) gave pressure estimates of 1.1-1.2 GPa for samples NG353, EG354, and NG421, and 1.3 GPa for sample SZ290 (at an average $T=750{ }^{\circ} \mathrm{C}$ for all samples), respectively. The $\mathrm{Zr}$-in rutile thermometry from rutile grains hosted in the garnet rim domains provides $710-800^{\circ} \mathrm{C}$ (Fig. 10).

\subsubsection{M3 stage}

The garnet-amphibole thermometry of Krogh Ravna (2000b) calibration has been tentatively applied to garnet rim composition in equilibrium with amphibole occurring in the corona 
Table 4c. Representative EMPA analyses of Plagioclase.

\begin{tabular}{|c|c|c|c|c|c|c|}
\hline \multirow{2}{*}{$\begin{array}{l}\text { Sample } \\
\text { Analysis }\end{array}$} & \multicolumn{2}{|c|}{ NG353 } & \multicolumn{2}{|c|}{ EG354 } & \multicolumn{2}{|c|}{ NG421 } \\
\hline & $\mathrm{Pl}$ & $\mathrm{Pl}$ & $\mathrm{Pl}$ & $\mathrm{Pl}$ & $\mathrm{Pl}$ & $\mathrm{Pl}$ \\
\hline $\mathrm{SiO}_{2}$ & 55.73 & 54.92 & 56.40 & 67.75 & 63.08 & 66.72 \\
\hline $\mathrm{TiO}_{2}$ & 0.05 & 0.01 & 0.01 & 0.01 & bdl & bdl \\
\hline $\mathrm{Al}_{2} \mathrm{O}_{3}$ & 29.30 & 29.64 & 28.89 & 21.13 & 23.37 & 20.63 \\
\hline $\mathrm{Cr}_{2} \mathrm{O}_{3}$ & 0.01 & 0.01 & bdl & bdl & bdl & bdl \\
\hline $\mathrm{Fe}_{2} \mathrm{O}_{3}$ & bdl & bdl & bdl & bdl & 1.08 & 0.15 \\
\hline $\mathrm{MnO}$ & 0.04 & bdl & bdl & bdl & bdl & bdl \\
\hline $\mathrm{MgO}$ & 0.01 & bdl & 0.01 & 0.01 & 0.02 & bdl \\
\hline $\mathrm{CaO}$ & 10.13 & 9.91 & 9.46 & 0.93 & 1.99 & 1.60 \\
\hline $\mathrm{Na}_{2} \mathrm{O}$ & 5.60 & 5.76 & 6.34 & 11.23 & 8.18 & 10.91 \\
\hline $\mathrm{K}_{2} \mathrm{O}$ & 0.16 & 0.37 & 0.08 & 0.04 & 2.14 & 0.11 \\
\hline Totals & 101.03 & 100.62 & 101.19 & 101.10 & 99.87 & 100.12 \\
\hline Oxygens & 8 & 8 & 8 & 8 & 8 & 8 \\
\hline $\mathrm{Si}$ & 2.47 & 2.45 & 2.50 & 2.93 & 2.50 & 2.92 \\
\hline $\mathrm{Ti}$ & 0.00 & 0.00 & 0.00 & 0.00 & 0.00 & 0.00 \\
\hline $\mathrm{Al}$ & 1.53 & 1.56 & 1.51 & 1.08 & 1.51 & 1.07 \\
\hline $\mathrm{Cr}$ & 0.00 & 0.00 & 0.00 & 0.00 & 0.00 & 0.00 \\
\hline $\mathrm{Fe}_{3}$ & 0.02 & 0.01 & 0.01 & 0.01 & 0.01 & 0.00 \\
\hline $\mathrm{Mn}$ & 0.00 & 0.00 & 0.00 & 0.00 & 0.00 & 0.00 \\
\hline $\mathrm{Mg}$ & 0.00 & 0.00 & 0.00 & 0.00 & 0.00 & 0.00 \\
\hline $\mathrm{Ca}$ & 0.48 & 0.48 & 0.45 & 0.04 & 0.45 & 0.08 \\
\hline $\mathrm{Na}$ & 0.48 & 0.50 & 0.55 & 0.94 & 0.55 & 0.93 \\
\hline K & 0.01 & 0.02 & 0.01 & 0.00 & 0.01 & 0.01 \\
\hline
\end{tabular}

bdl, below detection limit

structures and amphibole large grain. As expected, temperature estimates are lower than for $\mathrm{M}_{2}: 611-677^{\circ} \mathrm{C}$ for sample NG353, and $574-631^{\circ} \mathrm{C}$ for sample EG354. For all samples, the highest values were obtained when amphibole with higher $X_{\mathrm{Mg}}$ is chosen The pressure conditions were calculated by the application of the Kohn and Spear (1990) calibration on the amphibole and plagioclase occurring in symplectite and corona structures in textural equilibrium with garnet rims. Results, calculated in the range from 500 to $700{ }^{\circ} \mathrm{C}$, span from 0.35 to $0.62 \mathrm{GPa}$.

\subsection{5 $\mathrm{M}_{4}$-to-M5 $\mathbf{-}$ stage}

The late retrogressive $P-T$ conditions have been only qualitatively inferred by using the stability fields for the considered mineral assemblage. The presence of late-formed actinolite, chlorite, epidote, albite and prehnite-zeolite assemblages collectively indicate that final equilibration occurred under greenschist-to-sub-greenschist facies $P-T$ conditions. In particular, the late prehnite-bearing veins indicate the final $\mathrm{M}_{5}$ stage occurred at temeprature between 200 and $280^{\circ} \mathrm{C}$ for pressure less than $0.3 \mathrm{GPa}$. Furthermore, presence of wairakite-free zeolitic assemblages (heulandite) poses an upper limit for the temperature and pressure conditions during $\mathrm{M}_{5}\left(T<250{ }^{\circ} \mathrm{C}\right.$ and $P<0.2 \mathrm{GPa}$; Frey et al., 1991).

\subsection{Forward modelling}

Pseudosections in the NCFMASHTMnO $\left(\mathrm{Na}_{2} \mathrm{O}-\mathrm{CaO}-\mathrm{FeO}-\right.$ $\mathrm{MgO}-\mathrm{Al}_{2} \mathrm{O} 3-\mathrm{SiO}_{2}-\mathrm{H}_{2} \mathrm{O}-\mathrm{TiO}_{2}-\mathrm{MnO}-\mathrm{O}_{2}$ ) chemical system were calculated for the composition of sample NG421 (Table 1), containing garnet with only minor indication for corrosion. The following solid solution mixing models offered by Perple_X were considered in the calculations (details in solut09.dat; PERPLEX 07; database: hp04ver.dat): Amph(DPW) for amphibole, Grt(HP) for garnet, Cpx(HP) for clinopyroxene, feldspar for feldspar, melt(HP) for the melt phase, and $\mathrm{H}_{2} \mathrm{O}$ for the fluid phase; rutile and ilmenite were considered as pure phases. The small amount of whole rock $\mathrm{K}_{2} \mathrm{O}$ has been neglected because the current amphibole mixing models do not consider K-bearing end-members. For the calculations, water and $\mathrm{O}_{2}$ content were fixed to 1 (close to the measured value) and $0.01 \mathrm{wt} \%$, respectively. A representative pseudosection is shown in Fig. 11a.

The most important parameters to reconstruct the $P-T$ history of the Sabzevar granulites are the garnet compositions, the inclusion assemblages in garnet, and the distribution of Ti-bearing phases, with titanite, ilmenite and rutile growth tracing the different stages in the metamorphic evolution.

The $\mathrm{M}_{1}$ episode, predating major garnet growth, is characterized by the presence of relatively large titanite crystals. 
Table 4d. Representative EMPA of Amphibole.

\begin{tabular}{|c|c|c|c|c|c|c|c|}
\hline \multirow{2}{*}{$\begin{array}{l}\text { Sample } \\
\text { Analysis }\end{array}$} & \multicolumn{5}{|c|}{ NG353 NG421 } & \multirow{2}{*}{$\begin{array}{r}\text { EG354 } \\
\# 32-\mathrm{m}\end{array}$} & \multirow{2}{*}{$\begin{array}{r}\text { SZ290 } \\
\# 2-\mathrm{m}\end{array}$} \\
\hline & \#65-m & \#47-m & \#44-i & \#37-m & \#85-m & & \\
\hline $\mathrm{SiO}_{2}$ & 41.18 & 44.27 & 41.88 & 43.04 & 43.27 & 42.62 & 40.80 \\
\hline $\mathrm{TiO}_{2}$ & 2.13 & 1.37 & 1.38 & 1.78 & 1.82 & 2.09 & 1.21 \\
\hline $\mathrm{Al}_{2} \mathrm{O}_{3}$ & 12.67 & 11.67 & 11.62 & 11.88 & 12.08 & 12.08 & 14.68 \\
\hline $\mathrm{Cr}_{2} \mathrm{O}_{3}$ & 0.01 & 0.05 & 0.02 & 0.03 & 0.05 & 0.02 & 0.26 \\
\hline $\mathrm{Fe}_{2} \mathrm{O}_{3}$ & 2.16 & 1.22 & 2.21 & 2.59 & 2.96 & 2.43 & 2.92 \\
\hline $\mathrm{FeO}$ & 15.35 & 16.84 & 16.10 & 14.64 & 15.19 & 14.28 & 11.42 \\
\hline $\mathrm{MnO}$ & 0.28 & 0.21 & 0.14 & 0.17 & 0.25 & 0.18 & 0.11 \\
\hline $\mathrm{MgO}$ & 9.25 & 8.97 & 8.89 & 9.96 & 9.57 & 10.14 & 11.36 \\
\hline $\mathrm{CaO}$ & 11.50 & 11.07 & 10.96 & 11.15 & 10.93 & 11.15 & 11.38 \\
\hline $\mathrm{Na}_{2} \mathrm{O}$ & 1.77 & 2.09 & 1.90 & 1.70 & 1.86 & 1.98 & 2.81 \\
\hline $\mathrm{K}_{2} \mathrm{O}$ & 0.76 & 0.65 & 0.70 & 0.67 & 0.63 & 0.42 & 0.26 \\
\hline Totals & 96.84 & 98.29 & 95.58 & 97.35 & 98.31 & 97.14 & 96.91 \\
\hline Oxygens & 23 & 23 & 23 & 23 & 23 & 23 & 23 \\
\hline $\mathrm{Si}$ & 6.24 & 6.59 & 6.43 & 6.43 & 6.42 & 6.37 & 6.07 \\
\hline $\mathrm{Ti}$ & 0.24 & 0.15 & 0.16 & 0.20 & 0.20 & 0.24 & 0.14 \\
\hline $\mathrm{Al}$ & 2.26 & 2.05 & 2.10 & 2.09 & 2.11 & 2.13 & 2.57 \\
\hline $\mathrm{Cr}$ & 0.00 & 0.01 & 0.00 & 0.00 & 0.01 & 0.00 & 0.03 \\
\hline $\mathrm{Fe}_{3}$ & 0.25 & 0.14 & 0.26 & 0.29 & 0.33 & 0.27 & 0.33 \\
\hline $\mathrm{Fe}_{2}$ & 1.95 & 2.10 & 2.07 & 1.83 & 1.88 & 1.79 & 1.42 \\
\hline $\mathrm{Mn}$ & 0.04 & 0.03 & 0.02 & 0.02 & 0.03 & 0.02 & 0.01 \\
\hline $\mathrm{Mg}$ & 2.09 & 1.99 & 2.04 & 2.22 & 2.12 & 2.26 & 2.52 \\
\hline $\mathrm{Ca}$ & 1.87 & 1.77 & 1.80 & 1.79 & 1.74 & 1.79 & 1.81 \\
\hline $\mathrm{Na}$ & 0.52 & 0.60 & 0.57 & 0.49 & 0.54 & 0.57 & 0.81 \\
\hline $\mathrm{K}$ & 0.15 & 0.12 & 0.14 & 0.13 & 0.12 & 0.08 & 0.05 \\
\hline Sum & 15.68 & 15.58 & 15.67 & 15.59 & 15.60 & 15.61 & 15.87 \\
\hline
\end{tabular}

Mineral formula and ferric iron recalculation obtained through the software AX2000, enclosed in the THERMOCALC Package.

$\mathrm{m}$, matrix i, inclusion

A tentative Perple_X calculation considering $\mathrm{H}_{2} \mathrm{O}$-satured conditions results (not shown here) in a (fluorine-free) titanite stability field at low $T$ conditions $\left(<450^{\circ} \mathrm{C}\right)$. The presence of titanite at such conditions is consistent with only minor modal amounts of garnet $(<3 \%)$, predating the major garnet growth episodes. This early formed $\mathrm{M}_{1}$ garnet incorporated most of the Mn available in the rock, and can still be recognized as garnet core (Fig. 9).

To trace the prograde path towards the $M_{2 b}$ peak, the boundaries between the Ti-minerals and the pressure dependence of garnet modal content (Fig. 11b) are particularly significant. The calculations show that a relatively narrow reaction field of coexisting ilmenite and rutile exists, bounding a low-pressure, Ilm-bearing field from a high-pressure, Rt-bearing one (Fig. 11a). The textural evidence documenting rutile being late with respect to ilmenite $\left(\mathrm{Ilm}_{1}\right)$ indicates pressure increase. The recorded $\mathrm{M}_{2 \mathrm{a}}$ step of the metamorphic history is assumed to be preserved close to garnet cores that record the prograde chemical zoning (Fig. 9a-c). These are characterized by a $\mathrm{Mg}$ content of ca. 0.45 c.f.u., $\mathrm{Ca}$ of ca. 0.7 c.f.u., and inclusions of ilmenite 1 . Because of the presence of ilmenite, pressure conditions of about $0.7 \mathrm{GPa}$ at $650-680^{\circ} \mathrm{C}$ are estimated for the $\mathrm{M}_{2 \mathrm{a}}$ stage (Fig. 11a). These estimates are in line with those obtained from inverse thermobarometry (Fig. 10). Transition from $\mathrm{M}_{2 \mathrm{a}}$ to $\mathrm{M}_{2 \mathrm{~b}}$ is typified by crystallisation of garnet rim domains with dominant rutile instead of ilmenite. An inner rim of garnet, representing $\mathrm{M}_{2 \mathrm{~b}}$, contains inclusions of $\mathrm{Rt}$, high $\mathrm{Mg}$ content (up to 0.6 c.f.u.) and a nearly constant $\mathrm{Ca}$ content. These data indicate an increase in $P$ accompanied by minor heating along a path nearly parallel to the $\mathrm{Ca}$ isopleths. The estimated peak conditions of this $\mathrm{M}_{2}$ step attained at ca. $780^{\circ} \mathrm{C}$ and 1.1-1.2 GPa, limited by the upper pressure stability of plagioclase. Also in this case, results are in good accordance with the $\mathrm{Zr}$-in-rutile thermometry and the THERMOCALC calculations (Fig. 11a). Achievement of the peak $P-T$ conditions during $\mathrm{M}_{2 \mathrm{~b}}$ was accompanied with production of a small amount melt that is now visible as leucosome. Subsequent cooling resulted in resorption of garnet that is also indicated by Mn-rich seems (Fig. 9c), at first within the rutile 
M. Nasrabady et al.: Geodynamic significance of the Early Cretaceous Sabzevar granulites
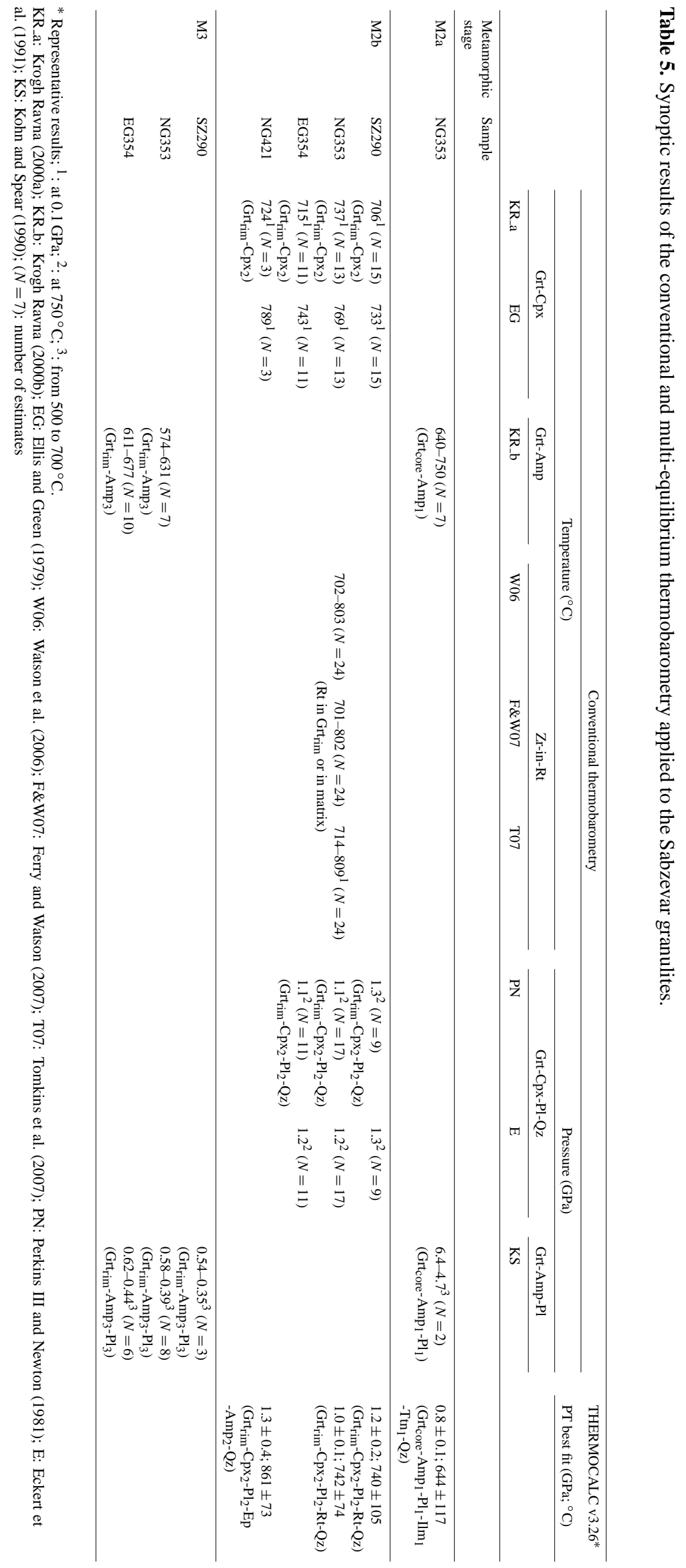
(a)

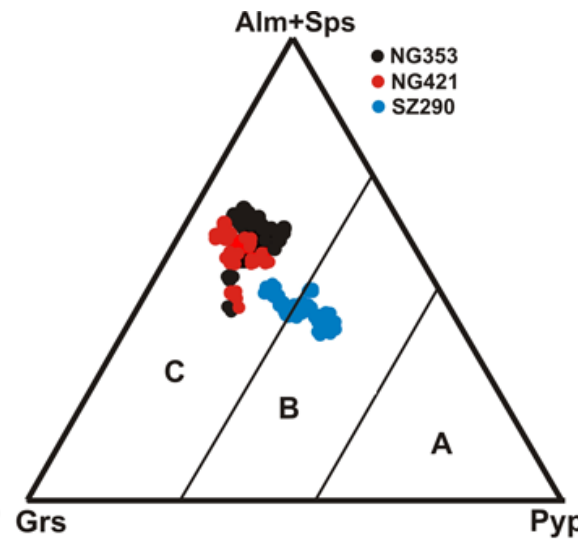

(b)

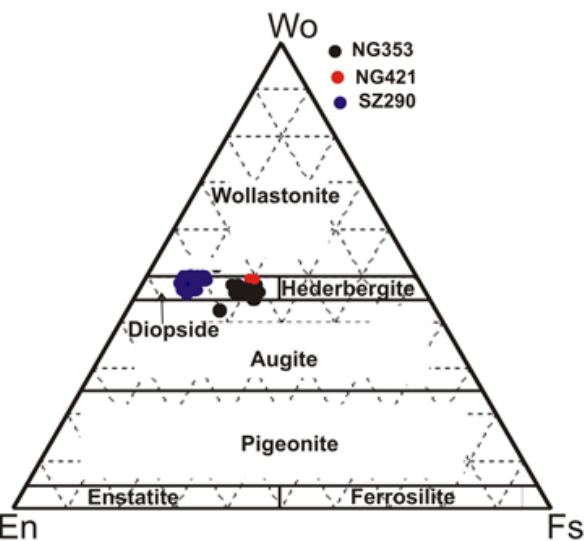

(c) $A b$

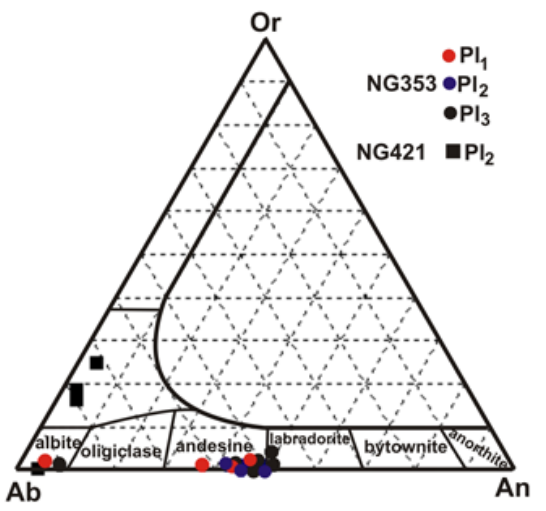

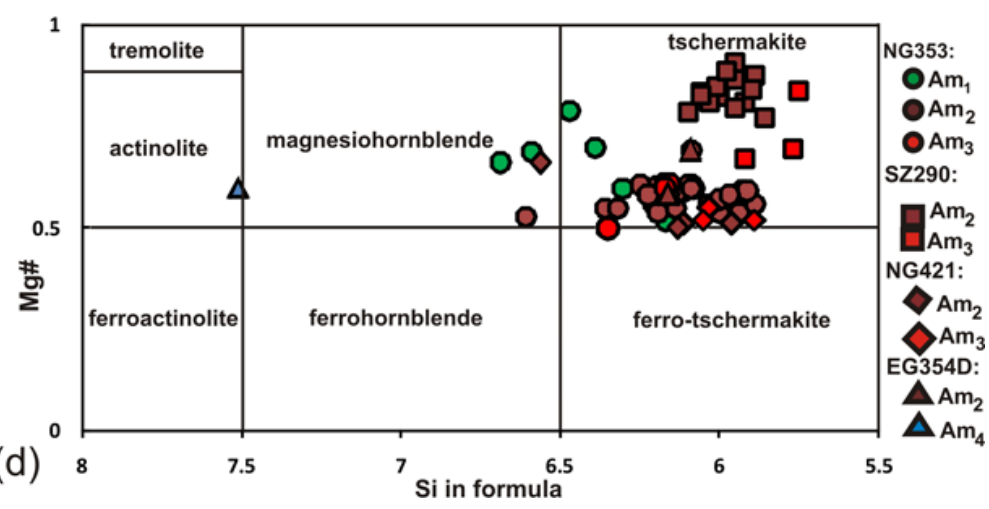

Fig. 8. Mineral classification diagrams. (a) Garnet, after Coleman et al. (1965); (b) pyroxene and (c) feldspar, after Deer et al. (1991); (d) amphibole, after Leake et al. (2004).

stability field and then within the ilmenite field. An important constraint on the $P-T$ path can be derived from garnet with zoning pattern such as Ng353_grt1 (Fig. 9b). This garnet type is in contact with a leucosome rim and shows little resorption. Its outer rim zoning is characterized by a significant increase in $\mathrm{Ca}$ (up to 0.9 c.f.u.), compensated by a decrease in Mg. Obviously, in this case the garnet outer rim adjacent to melt grew during cooling instead of being resorbed. Considering the calculated modal abundance of garnet, this feature requires some pressure increase during cooling, compatible with an anti-clockwise $P-T$ path (Fig. 11a). In the rock matrix, ilmenite almost completely replaced rutile. It only survived as shielded (mainly mono-phase) inclusion in garnet or in larger ilmenite aggregates. The cooling path is also imposed by the preservation of plagioclase in the matrix assemblages (Fig. 11a). Crystallisation of $\mathrm{Ttn}_{2}$ in leucosomes likely occurred close to the solidus during cooling. In contrast to early formed, relatively low- $T \operatorname{Ttn}_{1}$, the $\mathrm{Ttn}_{2}$ stability during this episode probably extended to significantly higher temperature because of the presence of significant amounts of fluorine in the residual melt (Tropper et al., 2002; Troitzsch and Ellis, 2002). Given that the water content is fixed to $1 \mathrm{wt} \%$ during the calculation of the pseudosection, resulting sub-solidus assemblages are mostly water-deficient, "dry" assemblages which cannot account for retrograde reactions in retrogressed samples (cf. Cpx stability at low pressure) containing minerals such as epidote, chlorite, actinolite, prehnite and zeolite appear. A Perple_X calculation of subsolidus phase relation with water-saturated conditions (not shown here) shows that during cooling epidote appears in the range of $550{ }^{\circ} \mathrm{C}$ during cooling. This temperature range fixes conditions for the composite $\mathrm{M}_{3}-\mathrm{M}_{4}$ retrogression.

We would emphasise here that various sources of uncertainty affect the results described above: (i) the amount of melt extracted during in situ melting, (ii) the incomplete mineral equilibrium (involving shielding of chemical components in garnet cores and in other minerals) and, more important, (iii) the uncertainties in the thermodynamic data set. The latter aspect particularly concerns the influence of minor elements such as $\mathrm{Ti}, \mathrm{F}, \mathrm{Fe}^{3+}$ on melt, amphibole and titanite compositions, as well as "extending" the application of melt thermodynamic parameters beyond the compositional range of their specified validity. A further source of uncertainty pertains to the estimation of the water content and its variation during the changing $P-T$ conditions. Accordingly, forward modelling of the Sabzevar granulites can be considered as tentative only and the results as semi-quantitative. Nonetheless, trial calculations with variations of $\mathrm{H}_{2} \mathrm{O}$ and $\mathrm{O}_{2}$ 
(A)
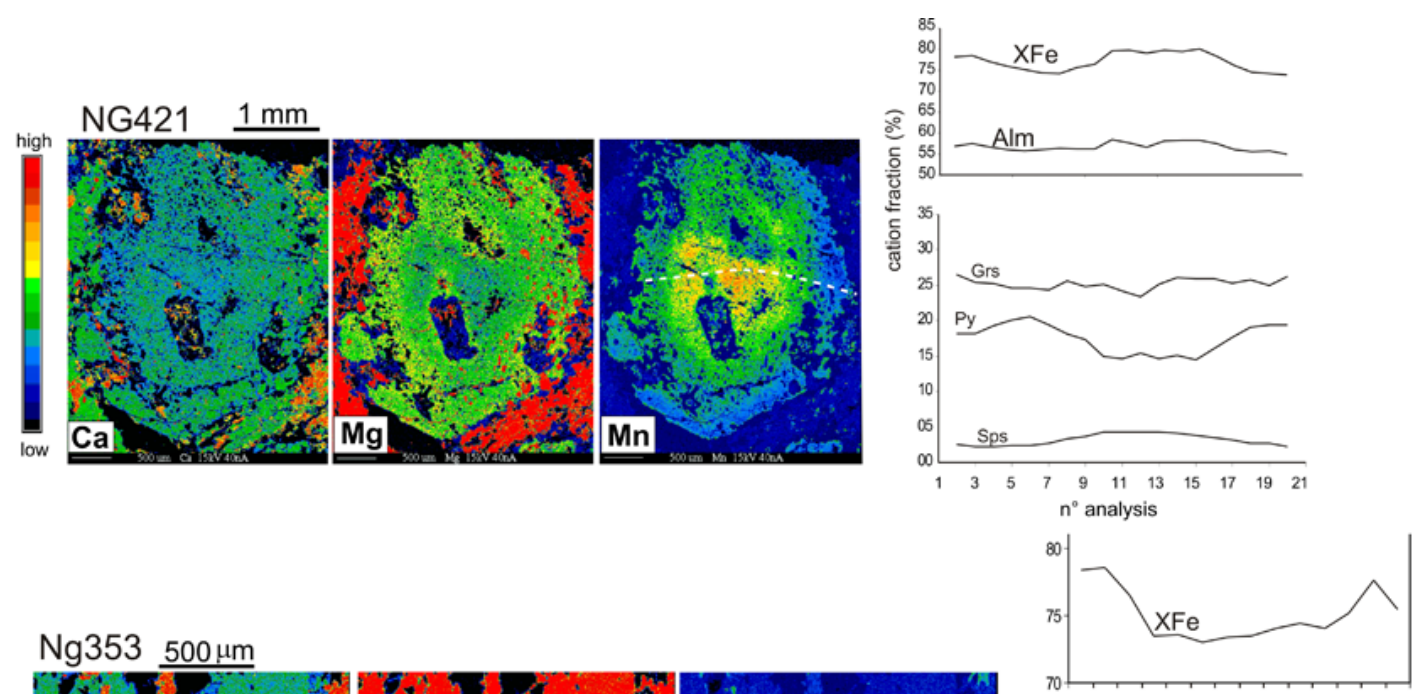

$\mathrm{Ng} 353 \underline{500 \mu \mathrm{m}}$

(B)
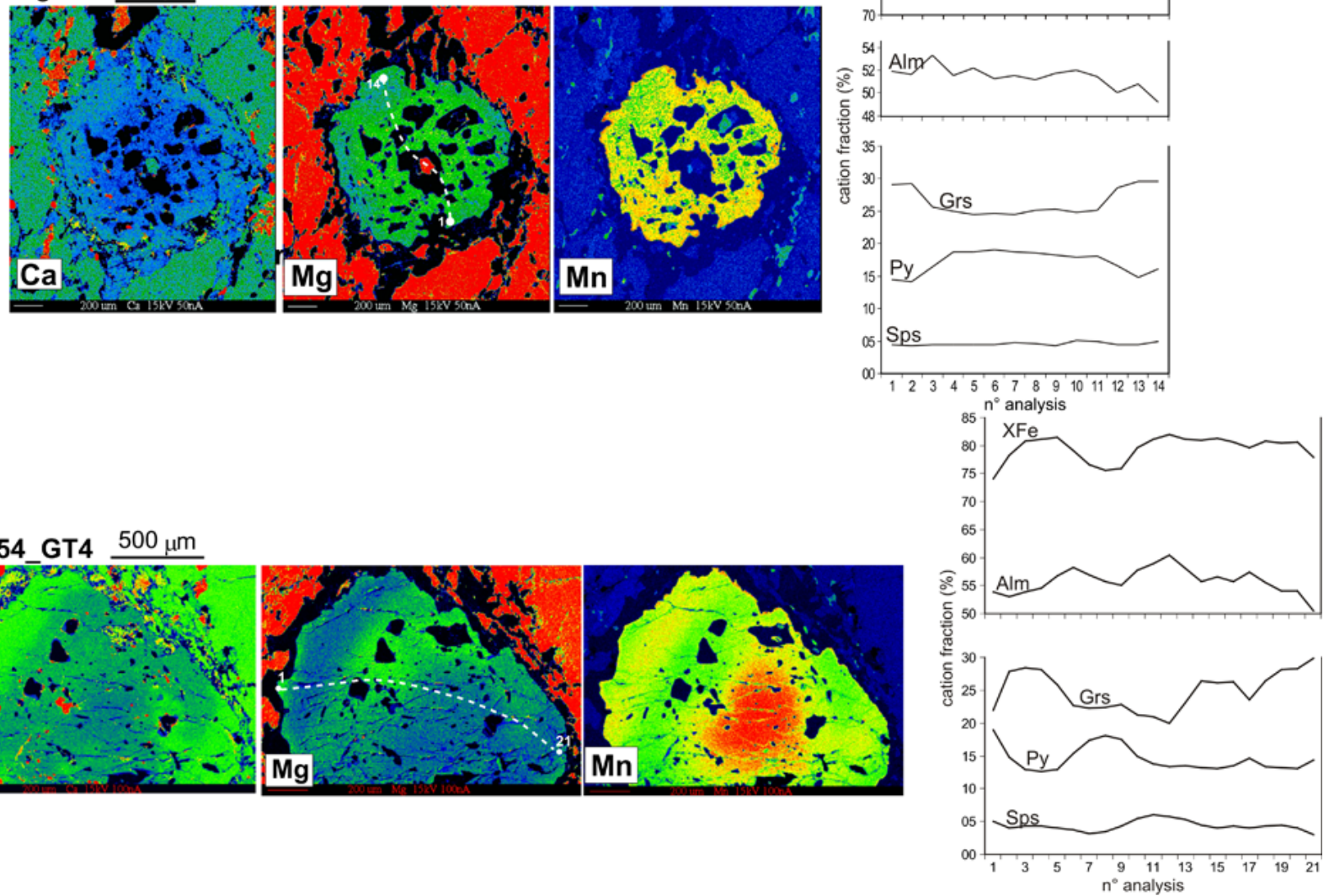

Fig. 9. Left: representative qualitative compositional cation map and quantitative cation profiles showing the variation in cation (Mg, $\mathrm{Fe}, \mathrm{Ca}$, $\mathrm{Mn}$ ) distribution in garnets from the Sabzevar granulites. Noteworthy features are the rimward increase in Ca (grossular) and $\mathrm{Mn}$ (spessartine, $\mathrm{Sps}$ ) and decrease in $\mathrm{Mg}$ (pyrope), which are indicative of retrograde diffusion and resorption. Alm, almandine; Grs, grossular; Py, pyrope; Sps, spessartine. Right: garnet compositions as obtained through EMPA chemical profiles across the same garnet grains (dashed white line).

contents, as well as addition of various amounts of tonalitic melt to the effective reactive composition did not result in significant modification of the general aspects of the derived $P-T$ path. Particularly, the $P-T$ path of the Sabzevar granulites is significantly constrained by (i) the stability of Ti minerals and (ii) the modal content of garnet reflect- ing episodes of growth/resorption of this mineral. In addition, the general validity of the obtained pseudosection to constrain the $P-T$ path of the Sabzevar granulites is confirmed by the overall compatibility with the results obtained from inverse (conventional and multi-equilibrium) thermobarometry. 


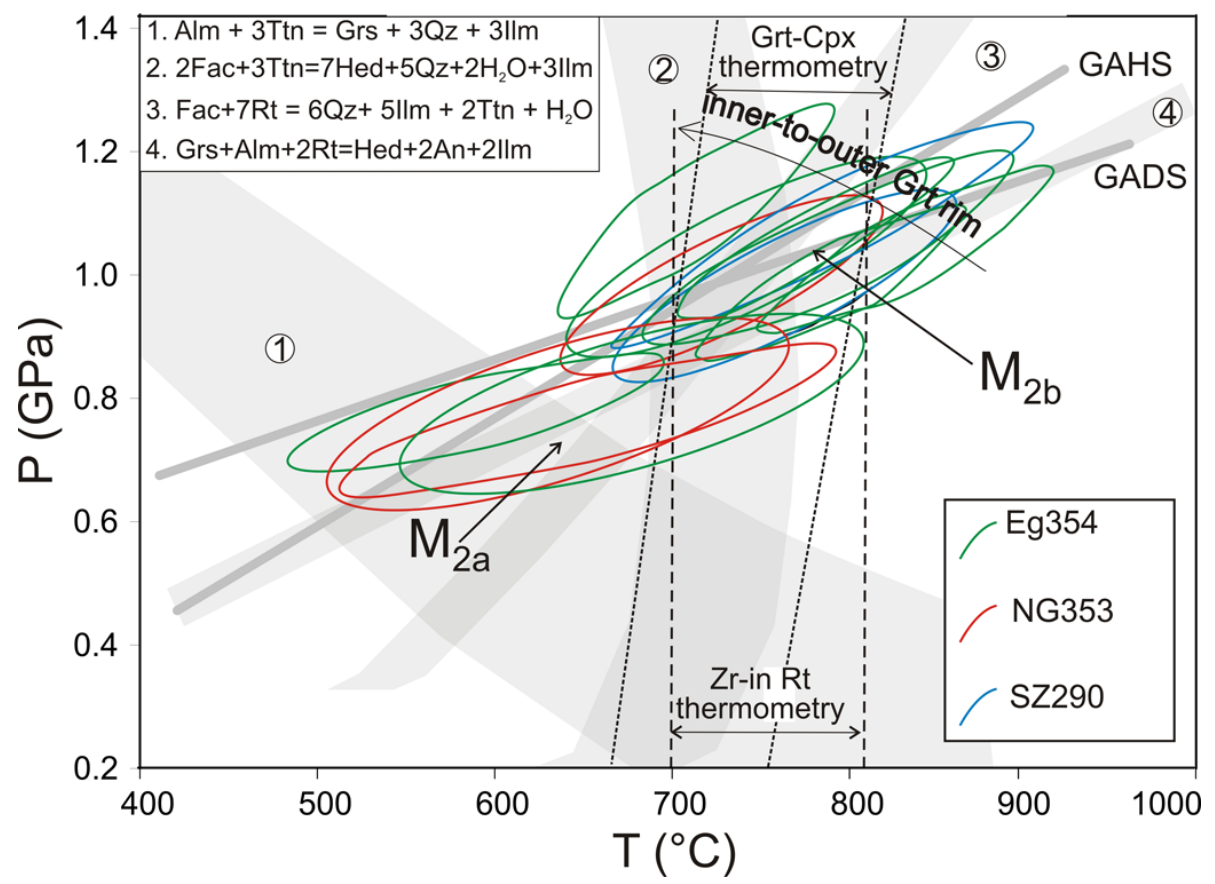

Fig. 10. Results from conventional thermobarometry, compared with those obtained from the THERMOCALC software in the average $P-T$ calculation mode. The latter results are shown as best fit ellipses, with error quoted at $1 \sigma$ level. The grey areas show the $P$ - $T$ fields calculated with the THERMOCALC software that pertain to the single reactions (numbered in the inset) that involve the Ti-bearing phases relevant for the main rock forming mineral assemblages (mineral abbreviations follow Whitney and Evans, 2010). See text for further details.

(a)
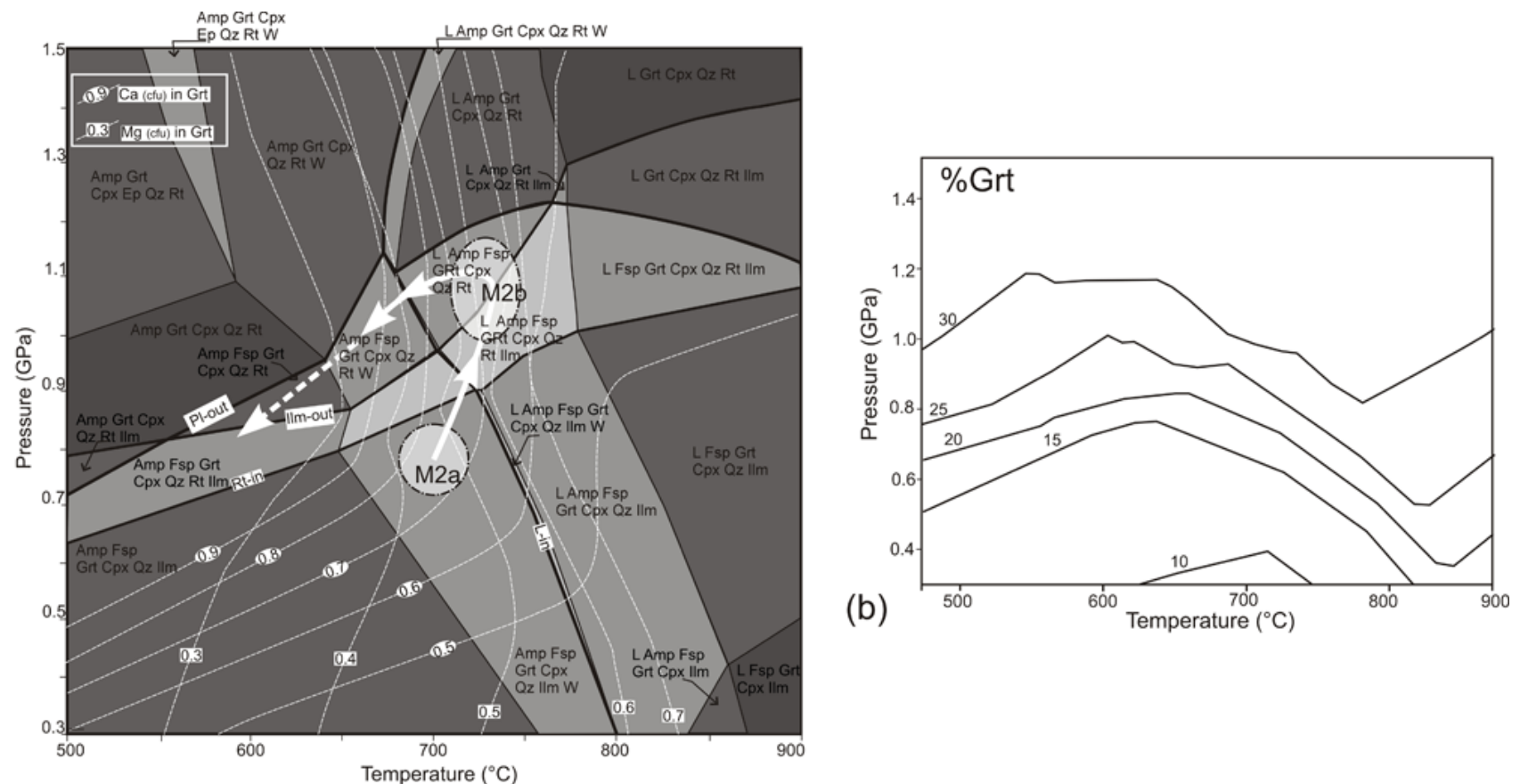

Fig. 11. (a) Representative $P-T$ pseudosection calculated for the Sabzevar granulites in the system NCFMASHMnTO with a bulk composition (wt \%) Na $\mathrm{Na}_{2} \mathrm{O}$ 1.35, $\mathrm{CaO}$ 10.87, $\mathrm{FeO} 15.53, \mathrm{MgO} 6.51, \mathrm{Al}_{2} \mathrm{O}_{3}$ 12.92, $\mathrm{SIO}_{2} 45.99, \mathrm{MnO}, 0.25, \mathrm{H}_{2} \mathrm{O} 1.0, \mathrm{Ti} \mathrm{O}_{2} 3.04, \mathrm{O}_{2} 0.01$ by using the Perple_X07 software. The dashed grey circles enclose the $P-T$ spaces in which the $\mathrm{M}_{1}$ and $\mathrm{M}_{2}$ (metamorphic climax) assemblages are inferred to be located. The dashed white arrow indicates the $P-T$ path followed by the Sabzevar granulites during their prograde and retrograde history. (b) Predicted modal distribution of garnet in the modelled $P-T$ field. Mineral abbreviations follow Whitney and Evans (2010) except for $\mathrm{L}$, melt and $\mathrm{W}, \mathrm{H}_{2} \mathrm{O}$. 


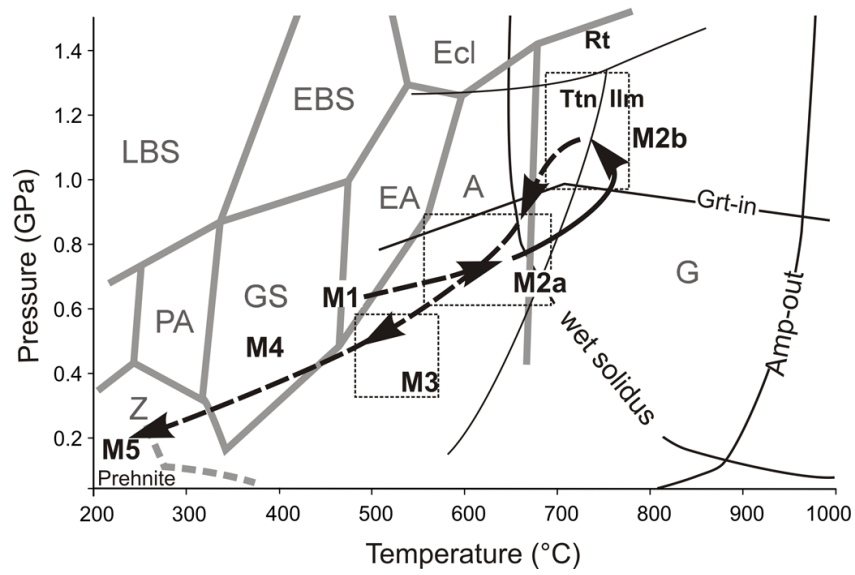

Fig. 12. Proposed synthetic $P-T$ path for the Sabzevar granulites. Metamorphic facies boundaries are after Bucher and Frey (2002). The grid showing wet melting regimes for basaltic system with stability of the main index minerals indicated is after Vielzieuf and Schmidt (2001). Experimentally determined $P-T$ field phase boundaries for Ti-phases (Ttn, Ilm, Rt) are after Liou et al. (1998). The prograde $\mathrm{M}_{1}$-to- $\mathrm{M}_{2}$ and the retrograde $\mathrm{M}_{3}$-to- $\mathrm{M}_{5}$ paths are only tentative. Key to symbols: A, amphibolite facies; EA, epidote amphibolite facies; EBS epidote blueschist facies; Ecl, eclogite facies; G, granulite facies; GS, greenschist facies; LBS, lawsoniteblueschist facies; PA, pumpelliite-actinolite facies; Z, zeolite facies. Mineral Abreviations are after Whitney and Evans (2010).

\section{Discussion}

\subsection{P-T path: proposal of an anticlockwise trajectory}

The metamorphic evolution reconstructed from the Sabzevar granulites attests to an early prograde stage starting from amphibolite-facies conditions $\left(\mathrm{M}_{1}\right.$ stage) with later equilibration under granulite-facies peak conditions $\left(\mathrm{M}_{2}\right.$ stage). The peak mineral assemblage described in this study $(\mathrm{Grt}+\mathrm{Cpx}+\mathrm{Pl}+\mathrm{Rt} \pm \mathrm{Amp} \pm \mathrm{Qz})$ is indicative of the Opx-free HP granulite facies (Pattison, 2003; O'Brien and Rötzler, 2003). According to thermobarometric calculations, peak metamorphism occurred at ca. $780^{\circ} \mathrm{C}$ and $1.1-$ $1.2 \mathrm{GPa}$, as indicated by assemblage $\mathrm{M}_{2 \mathrm{a}}$. This is compatible with (i) occurrence of rutile and garnet in MORBlike rocks, which indicate minimum pressure of about 0.10.12 GPa (Ernest and Liu, 1998); and (ii) presence of Cpx instead of Opx (e.g. O’Brien and Rötzler, 2003). Calculated peak $P-T$ conditions are also compatible with partial melting of amphibolite as they are located above the $\mathrm{H}_{2} \mathrm{O}$-saturated basaltic solidus (Vielzieuf and Schmidt, 2001).

Textural evidence for in situ amphibolite dehydratation melting (see also Rossetti et al., 2010) attests to migmatisation occurring during this prograde history and during attainment of the granulite climax. In addition, according to the calculated \% grt isopleths (Fig. 11b), garnet growth close to peak temperature indicates significant pressure in- crease. Even during the initial cooling episode, further pressure increase is suggested by Ca-rich/Mg-poor garnet rims (Fig. 9b), formed during melt crystallization. The pressure increase close to peak temperature, the late- $\mathrm{M}_{2}$ cooling with some pressure increase and the late stage formation of ilmenite-bearing matrix assemblage collectively suggest a anticlockwise $P-T$ loop (pressure axis upward; Fig. 12), departing from a prograde Barrovian-type metamorphic gradient (in the order of $25^{\circ} \mathrm{C} \mathrm{km}^{-1}$ ). The metamorphic peak was followed by a polyphase metamorphic retrogression $\left(\mathrm{M}_{3}\right.$-to$\mathrm{M}_{5}$ stages), tracing the progressive cooling and exhumation from upper-greenschist/amphibolite facies (assemblage $\mathrm{M}_{3}$ ) down to the stability field of prehnite and zeolite (assemblage $\mathrm{M}_{5}$ ) (Fig. 12).

\subsection{A possible geodynamic scenario}

The whole rock geochemical data presented above document that the Early Cretaceous (Albian) Sabzevar granulites likely derive from a MORB-type precursor and therefore represent remnants of a former oceanic crust (hereafter referred as proto-Sabzevar Ocean to distinguish it from the later formed Sabzevar Ocean) affected by subduction zone metamorphism. The thermobarometric estimates of peak metamorphism demonstrate incipient migmatisation of the oceanic protolith already at relatively shallow depths (ca. $40 \mathrm{~km}$ ) and hence suggest for a high heat flow subduction channel (cf. Peacock and Wang, 1999).

Modelling of the thermal and rheological structure of subduction zones as well as fossil and active examples of oceanic subduction zones (e.g. Peacock et al., 1994, 2005; Peacock and Wang, 1999; Hacker et al., 2003; Conder, 2005; Bebout et al., 2007; García-Casco et al., 2007; Guilmette et al., 2008) have documented that cool geothermal conditions can not be generalized to any oceanic subduction and that "warmer" geothermal environments such as those documented in this study do not necessarily require an atypical tectonic environment in oceanic subduction settings. The most favourable conditions for a hot subduction setting pertain to slab edges and windows (Kincaid and Griffiths, 2004; Thorkelson and Breitsprecher, 2005), sub-horizontal or flat subduction (Gutcher et al., 2000), onset of subduction (e.g. Gerya et al., 2002), or subduction of a young slab or a ridge (e.g. Peacock et al., 1994; Peacock, 1996; Okudaira and Yoshitake, 2004). High heat-flow subduction settings also provide appropriate conditions to cause slab melting and generate the tonalite-trondhjemite-granodiorite magmatic suites (Martin et al., 2005, and references therein).

Peacock et al. (1994) documented that young (0-5 Ma) crust that is slowly subducting $\left(1 \mathrm{~cm} \mathrm{yr}^{-1}\right)$ into a hot mantle at constant shear may produce a subduction zone metamorphism with high $T / P$ ratios and peak metamorphic conditions compatible with those of the Sabzevar HP granulites. Such metamorphic conditions are typical of most dynamothermal soles in ophiolites (and particularly of the early stages 


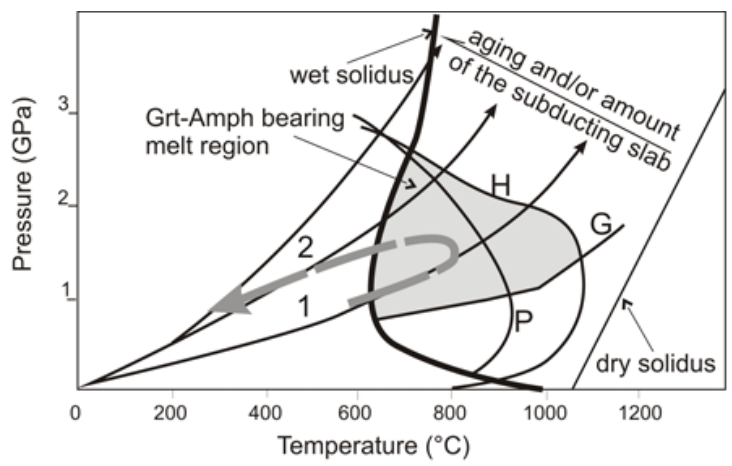

1. Onset of oceanic subduction; hot subduction setting and partial melting at depth (Early Cretaceous)

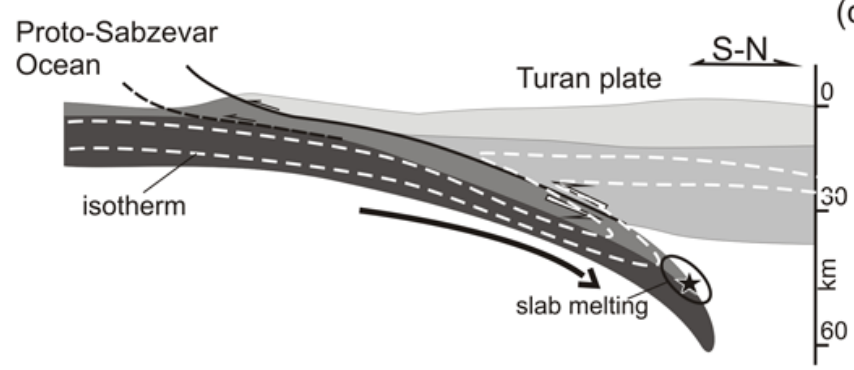

2. Continuos subduction, underthrusting at depth and cold exhumation of the Sabzevar granulites (cooling down the subduction channel)

Fig. 13. Conceptual two-stage geodynamic model to accomplish for the anticlockwise $P-T$ evolution recorded by the Sabzevar granulites. This $P-T$ path is interpreted as consequence of transition from an infant to a mature stage of subduction of the Proto-Sabzevar Ocean below the Turan plate. The top panel (modified and re-adapted after Peackock et al., 1994 and Martin, 1999) show the dry and wet solidus of tholeiite and the inferred $P-T$ trajectories and geothermal gradients in the subduction channel as a function of the age and/or amount of the subducted oceanic lithosphere. Trajectory 1 and 2 refers to a nascent and mature subduction, respectively. Slab melting is predicted only when young lithosphere subducts or at the early stages of subduction. The dashed grey arrow schematically depicts the $P-T$ evolution of the Sabzevar granulites. Key to labels: G, and P, line delimiting garnet and plagioclase stability, respectively; $\mathrm{H}$, hornblende-out.

of subduction zone metamorphism), which also show anticlockwise $P-T$ paths (Spray, 1984; Jamieson, 1986; Peacock, 1987; Dilek and Whitney, 1997; Wakabayashi and Dilek, 2000; Guilmette et al., 2008). Peacock et al. (1994) also showed that aging of a nascent subduction zone and/or increase of the subducted lithosphere rapidly results in cooling of the subducted crust and the subduction channel, shifting the metamorphic gradient towards higher $P / T$ ratios. We thus propose that the anticlockwise $P-T$ trajectory followed by the Sabzevar granulites is the record of a progressively colder thermal regime (and hence cold exhumation) within the subduction channel in consequence of the continuous underthrusting of the oceanic material at the subduction front during the transition from infant to mature subduction of the proto-Sabzevar Ocean (Fig. 13).

Rossetti et al. (2010) tentatively linked the proto-Sabzevar Ocean (of probable Early Cretaceous age) to the Sistan Ocean to the East of the Central East Iranian Microontinent
(Fig. 1; cf. Tirrull et al., 1983; McCall, 1997), where Early Cretaceous (ca. $125 \mathrm{Ma}$ in age) subduction zone metamorphism was reported based on Ar-Ar geochronology (Footohi $\mathrm{Rad}$ et al., 2009). New $\mathrm{Rb}-\mathrm{Sr}$ results (internal mineral isochrons from the eclogitic rocks of the Sistan area indicate a regionally consistent Late Cretaceous (about $85 \mathrm{Ma}$ ) age clustering, with considerably younger ages than those indicated by Ar-Ar geochronology (Bröcker et al., 2011). These new chronological data thus impose a critical re-evaluation of the former interpretation. The proto-Sabzevar Ocean can be alternatively interpreted as a small marginal basin formed in the upper-plate of the Neothetyan subduction, separated from the Sistan Ocean and with an independent evolution. This oceanic basin formed in a inner position with respect to the Tertiary Sabzevar structural zone and can be tentatively correlated with the south-central Iran ophiolitic domains. Nevertheless, formation ages compatible with the Albian age of the Sabzevar granulites are only reported from the Eastern 
ophiolites (Sistan suture; Fig. 1b), where an Early Cretaceous (pre-Aptian) timing for opening of the Sistan Ocean has been documented (Babazadeh and De Wever, 2004).

Independent of which interpretation is adopted, by integrating our reconstruction with the tectono-metamorphic evolution of the Neotethyan subduction (Zagros Blueschists) along the Sanandaj-Sirjan Zone (Fig. 1) as reconstructed in the work of Agard et al. (2006), consumption of the oceanic lithosphere along the Iranian tract of the HimalayanAlpine convergence zone during the Early Cretaceous testifies to different thermal structures in the active subduction systems. In particular, being the thermal structure in subduction channels and orogenic convergence zones modulated by the relative importance of heat advection to diffusion (e.g. Peackock et al., 1994; Peackock and Wang, 1999; Faccenna et al., 2001; Sandiford, 2002), conduction-dominated (the nascent and warm Proto-Sabzevar subduction, thermal gradient of ca. $25^{\circ} \mathrm{C} \mathrm{km}^{-1}$ ) and advection-dominated (the mature and cold Neotheyan subduction, thermal gradient of ca. $10^{\circ} \mathrm{C} \mathrm{km}^{-1}$ ) subduction channels can be recognised in the Iranian region. This evidence suggests a heterogeneous space-time distribution in the mode and style of oceanic subduction in the upper-plate of the subducting Neo-Thetyan ocean, a likely consequence of the different types of oceanic (mature vs. young) lithosphere that were being subducting.

\section{Conclusions}

The geochemical and petrological study of the Sabzevar H $P$ granulites provide new insights on the tectono-metamorphic evolution experienced by the remnants of peri-Tethyan oceanic branches that surround the Central East Iranian Microcontinent (Fig. 1). In particular, evidence for a nascent oceanic subduction zone in central Iran (Sabzevar structural zone) during the Early Cretaceous is documented.

Based on the regional scenario, our results suggest that punctuated events of subduction of short-lived marginal oceanic domains accompanied the long-lasting (Mesozoicto-Tertiary) history of Neotethyan subduction along the Sanandaj-Sirjan zone. Consequently, diachronic and independent tectonic evolutions of the different ophiolitic domains surrounding the CEIM have to be taken into account for future investigations.

Acknowledgements. We thank Amir and Habib for assistance during field work. D. Cozzupoli participated to the field work and is thanked for useful discussion together with H. J. Massonne, C. Faccenna and M. Mattei. M. Bröcker and an anonymous reviewer provide valuable comments that improved the overall quality of the ms. Comments and editorial handling by N. Arndt are also acknowledged.

Edited by: N. T. Arndt

\section{References}

Abbotto R. N. and Green Wood J. P.: Retrograde metamorphim of eclogite in the Southern Appalachian Mountains, U.S.A., a case involving seamount subduction?, J. Metamorph. Geol., 19, 433443, 2001.

Agard, P., Monie, P., Gerber, W., Omrani, J., Molinaro, M., Labrousse, L., Vrielynck, B., Meyer, B., Jolivet, L., and Yamato, P.: Transient synobduction exhumation of Zagros blueschists inferred from pressure, temperature, deformation, time and kinematic constraints: Implications for Neotethys wedge dynamics, J. Geophys. Res., 111, B11401, doi:10.1029/2005JB004103, 2006.

Agard, P., Yamato, P., Jolivet, L., and Burov, E.: Exhumation of oceanic blueschists and eclogites in subduction zones: timing and mechanisms, Earth-Sci. Rev., 92, 53-79, 2009.

Alavi-Tehrani, N.: Geology and petrography in the ophiolite range NW of Sabzevar, Khorasan/Iran with special regards to metamorphism and genetic relations in an ophiolite suite, Geol. Survey of Iran, Rep. No.: 43, 1977.

Arevalo Jr., R. and McDonough, W. F.: Chemical variations and regional diversity observed in MORB, Chem. Geol., 271, 70-85, 2010.

Babazadeh, S. A. and De Wever, P.: Early Cretaceous radiolarian assemblages from radiolarites in the Sistan Suture (eastern Iran), Geodiversitas, 26, 185-206, 2004.

Bagheri, S. and Stampfli, G. M.: The Anarak, Jandaq and Poshte-Badam metamorphic complex in central Iran: New geological data, relationships and tectonic implications, Tectonophysics, 451, 123-155, 2008.

Baroz, F., Macaudiere, J., Montigny, R., Noghreyan, M., Ohnenstetter, M., and Rocci, G.: Ophiolites and related formations in the central part of the Sabzevar (Iran) and possible geotectonics reconstructions, N. Jb. Geolog. Paläontolog. Abh., 168, 358-388, 1984.

Bebout, G. E., Ryan J. G., Leeman W. P., and Bebout, A. E.: Fractionation of trace elements by subduction-zone metamorphism: effect of convergent-margin thermal evolution, Earth Planet. Sc. Lett., 171, 63-81, 2007.

Berger, J., Caby, R., Liedeois, J. P., Jean-Claude, C., Mercier, J. C., and Demaiffe, D.: Dehydration, melting and related garnet growth in the deep root of the Amalaoulaou Neoproterozoic magmatic arc (Gourma, NE Mali), Geol. Mag., 146, 173-186, 2009.

Besse, J., Torcq, F., Gallet, Y., Ricou, L. E., Krystyan, L., and Saidi, A.: Late Permian to late Triassic paleomagnetic data from Iran: constraints on migration of the Iranian block through the Tethyan ocean and initial destruction of Pangea, Geophys. J. Int., 135, 77-92, 1998.

Bröcker, M., Fotoohi Rad, R., Theunissen, S., Burgess, R., and Salimi, Z.: The age of high-pressure metamorphism and epidote amphibolite facies overprinting in the Sistan suture zone, eastern Iran, ILP Workshop, Nature of of the Place interface in subduction zones, 2-7 July, Sampeyre, Torino, Abstract Volume, 2010.

Brown, M.: Duality of thermal regimes is the distinctive characteristic of plate tectonics since the Neoarchean, Geology, 34, 961964, 2006.

Brown, M.: Paired metamorphic belts revised, Gondwana Res., 18, 46-59, 2010.

Bucher, K. and Frey, M.: Petrogenesis of Metamorphic Rocks, 7th edn., Springer-Verlag, Berlin, 2002. 
Carswell, D. A.: Eclogites and eclogite facies: definitions and classification, in: Eclogite Facies Rocks, edited by: Carswell, D. A., Blackie, London, 219-221, 1990.

Cawood, P. A., Kröner, A., Collins, W. J., Kusky, T. M., Mooney, W. D., and Windley, B. F.: Accretionary orogens through Earth history, in: Earth Accretionary Systems in Space and Time, edited by: Cawood, P. A. and Kröner, A., J. Geol. Soc. London, Special Publication, 318, 1-36, 2009.

Coleman, R. G., Lee, D. E., Beatty, L. B., and Brannock, W. W.: Eclogites and eclogites: their differences and similarities, Geol. Soc. Am. Bull., 76, 483-508, 1965.

Conder, J. A.: A case for hot slab surface temperatures in numerical viscous flow models of subduction zones with an improved fault zone parameterization, Phys. Earth Planet. Int., 149, 155-164, 2005.

Connolly, J. A. D.: Computation of phase equilibria by linear programming: a tool for geodynamic modeling and its application to subduction zone decarbonation, Earth Planet. Sc. Lett., 236, 524-541, 2005.

Delaoye, M. and Desmons, J.: Ophiolites and mélange terranes in Iran. A geochronological study and paleotectonic implications, Tectonophysics, 68, 83-111, 1980.

Dercourt, J., Gaetani, M., Vrielynck, B., Barrier, E., Biju-Duval, B., Brunet, M. F., Cadet, J. P., Crasquin, S., and Sandulescu, M. (Eds.): Atlas Peri-Tethys Paleoegeographical Maps, vol. IXX. CCGM/CGMW, Paris, 24 maps and explanatory note, 1269,2000

Dewey, J. F. and Bird, J. M.: Mountain belts and the new global tectonics, J. Geophys. Res., 75, 2625-2647, 1970.

Dilek, Y. and Whitney, D. L.: Counterclockwise P-T-t trajectory from the metamorphic sole of a Neo-Tethyan ophiolite (Turkey), Tectonophysics, 280, 295-310, 1997.

Eckert, J. O., Newton, R. C., and Kleppa, O. G.: The $\Delta \mathrm{H}$ of reaction and recalibration of garnet-pyroxene-plagioclase-quartze geobarometers in the CMAS system by solution calorimetry, Am. Mineral., 76, 148-160, 1991.

Ellis, D. J. and Green, D. H.: An experimental study of the effect of $\mathrm{Ca}$ upon garnet-clinopyroxene $\mathrm{Fe}-\mathrm{Mg}$ exchange equlibria, Contr. Min. Petrol. 71, 13-22, 1979.

Engvik, A. K., Tveten, E., Bingen, B., Viola, G., Erambert, M., Feito, P., and De Azavedo, S.: P-T-t evolution and textural evidence for decompression of Pan-African high-pressure granulites, Lurio Belt, north-eastern Mozambique, J. Metamorph. Geol., 25, 935-952, 2007.

Ernest, W. G. and Liu, J.: Experimental phase-equilibrium study of Al- and Ti-contents of calcic amphibole in MORB-A semiquantitative thermobarometer, Am. Mineral. 83, 952-969, 1998.

Faccenna, C., Becker, T. W., Lucente, F. P., Jolivet, L., and Rossetti, F.: History of subduction and Back-arc extension in the Central Mediterranean, Geophys. J. Int., 145, 809-820, 2001.

Ferry, J. and Watson, E. B.: New thermodynamic models and revised calibrations for the Ti-in-zircon and $\mathrm{Zr}$-in-rutile thermometers, Contr. Mineral. Petrol. 154, 429-437, 2007.

Fotoohi Rad, G. R., Droop, G. T. R., and Burges, R.: Early Cretaceous exhumation of high-pressure metamorphic rocks of the Sistan Suture Zone, eastern Iran, Geol. J., 44, 104-116, 2009.

Frey, M., De Capitani, C., and Liou, J. G.: A new petrogenetic grid for low-grade metabasites, J. Metamorph. Geol., 9, 479$509,1991$.
Frost, B. R., Frost, C. D., Hulsebosch, T. P., and Swapp, S. M.: Origin of the charnockites of the Louis Lake batholith, Wind River Range, Wyoming, J. Petrol., 41, 1759-1776, 2000.

Ganguly, J.: Diffusion kinetics in minerals: principles and applications to tectono-metamorphic processes, EMU notes in Mineralogy, 4271-309, 2002.

García-Casco, A., Lázaro, C., Torres-Roldán, R. L., Núñez Cambra, K., Rojas Agramonte, Y., Kröner, A., Neubauer, F., Millán, G., and Blanco Quintero, I.: Partial melting and counterclockwise PT path of subducted oceanic crust (Sierra del Convento mélange, Cuba, J. Petrol., 49, 129-161, 2007.

Garrido, C. J., Bodinier, J. L., Burg, J. P., Zeilinger, G., Hussain, S. S., Dawood, H., Chaudhry, M. N., and Gervilla, A. F.: Petrogenesis of mafic garnet granulites in the lower crust of the Kohistan palaeoarc complex (Northern Pakistan): Implications for intracrustaldifferentiation of island arcs and generation of continental crust, J. Petrol., 47, 1873-1914, 2006.

Gerya, T. V., Stoeckhert, B., and Perchuk, A. L.: Exhumation of high-pressure metamorphic rocks in a subduction channel: a numerical simulation, Tectonics, 21, 1056, doi:10.1029/2002TC001406, 2002.

Ghasemi, A. and Talbot, C. J.: A new tectonic scenario for the Sanandaj-Sirjan Zone (Iran), J. Asian Earth Sci., 26, 683-693, 2006.

Golonka, A. J.: Plate tectonic evolution of the southern margin of Eurasia in the Mesozoic and Cenozoic, Tectonophysics, 381, 235-273, 2004.

Guilmette, C., Hebert, R., Dupuis, C., Wang, C., and Li, Z.: Metamorphic history and geodynamic significance of high-grade metabasites from the ophiolitic mélange beneth the Yarlung Zangbo ophiolites, Xigaze area, Tibet, J. Asian Earth Sci., 32, 423-437, 2008.

Gutcher, M. A., Maury, R., Eissen, J. P., and Bourdon, E.: Can slab melting cuased by flat subduction?, Geology, 28, 535-538, 2000.

Hacker, B. R., Abers, G. A., and Peacock, S. M.: Subduction Factory 1. Theoretical mineralogy, densities, seismic wave speeds, and $\mathrm{H}_{2} \mathrm{O}$ contents, J. Geophys. Res., 108, 2029 , doi:10.1029/2001JB001127, 2003.

Harly, S. L.: The origin of granulites: A metamorphic perspective, Geol. Mag., 126, 215-247, 1989.

Hartel, T. H. D. and Pattison, D. R. M.: Genesis of the Kapuskasing (Ontario) migmatitic mafic granulites by dehydration melting of amphibole: the importance of quartz to reaction progress, J. Metamorph. Geol. 14, 591-611, 1996.

Hoffman, E. L.: Instrumental Neutron Activation in Geoanalysis, J. Geochem. Explor., 44, 297-319, 1992.

Holland, T. J. B. and Powell, R.: An internally consistent thermodynamic data set for phases of petrological interest, J. Metamorph. Geol., 16, 309-343, 1998.

Irvine, T. N. and Baragar, W. R. A.: A guide to the chemical classification of the common volcanic rocks, Can. J. Earth Sci., 8, 523-548, 1971.

Jamison, R. A.: P-T path from high temperature shear zones beneath ophiolites, J. Metamorph. Geol., 4, 3-22, 1986.

John, T., Schenk, V., Haase, K., Scherer, E., and Tembo, F.: Evidence for a Neoprotrozoic ocean in south-central Africa from mid-ocean ridge type geochemical signature and pressure temperature estimates of Zambian eclogites, Geology, 31, 243-246, 2003. 
Jolivet, L., Faccenna, C., Goffe, B., Burov, E., and Agard, P.: Subduction tectonics and exhumation of high-pressure metamorphic rocks in the Mediterranean orogens, Am. J. Sci., 303, 353-409, 2003.

Kincaid, C. and Griffiths, R. W.: Variability in flow and temperatures within mantle subduction zones, Geochem. Geophys. Geosyst., 5, Q06002, doi:10.1029/2003GC000666, 2004.

Kohn, M. J. and Spear, F. S.: Two new geobarometers for garnet amphibolites, with applications to Southeastern Vermont, Am. Mineral., 75, 89-96, 1990.

Krogh Ravna, E.: The garnet-clinopyroxene Fe-Mg geothermometer: an update calibration, J. Metamorph. Geol., 18, 211-219, 2000a.

Krogh Ravna, E.: Distribution of $\mathrm{Fe}$ and $\mathrm{Mg}$ between coexisting garnet and hornblende in synthetic and natural systems: an empirical calibration of the garnet-hornblende Fe-Mg geothermometer, Lithos, 53, 305-321, 2000b.

Le Bas, M. J., Le Maitre, R. W., and Woolley, A. R.: The construction of the total alkali-silica chemical classification of volcanic rocks, Mineral. Petrol., 46, 1-22, 1992.

Leake, B. E., Alan, R. W., William, D. B., Ernst, A. J. B., Giovanni, F., Jeol, D. J., Frank, C. H., Hanan, J. K., Vladimir, G. K., John, C. S., Nicholas, C. N. S., and Eric, J. W. W.: Nomenclature of amphiboles: Additions and revisions to the International Mineralogical Associations amphibole nomenclature, Am. Mineral., 89, 883-887, 2004.

Lensch, G., Mihm, A., and Alavi Tehrani, N.: Petrography and geology of the ophiolite belt north of Sabzevar Khorasan (Iran), N. Jb. Geolog. Paläontolog. Mon., 131, 156-178, 1977.

Liou, J. G., Zhang, R., Ernst, W. G., Liu, J., and McLimans, R.: Mineral parageneses in the Piampaludo eclogitic body, Gruppo di Voltri, western Ligurian Alps. Schweizerische, Mineral. Petrograph. Mitt., 78, 317-355, 1998.

Liu, J., Bohlen, S. R., and Ernest, W. G.: Stability of hydrous phases in subducting oceanic crust, Earth Planet. Sc. Lett., 143, 161$171,1996$.

Maheo, G., Bertrand, H., Guillot, S., Villa, I. M., Keller, F., and Capiez, P.: The south Ladakh ophiolites (NW Himalaya, India): an intraoceanic tholeiitic origin with implication for the closure of the Neo-Tethys, Chem. Geol., 203, 273-303, 2004.

Manning, C. E. and Bohlen, S. R.: The reaction titanite + kyanite $=$ anortite + rutile and titanite-rutile barometry in eclogites, Contrib. Mineral. Petr., 109, 1-9, 1991.

Martin, H.: Adakitic magmas: modern analogues of Archaean granitoids, Lithos, 46, 411-429, 1999.

Martin, H., Smithies, R. H. M., Rapp, R., Moyen, J. F., and Champion, D.: An overview of adakite, tonalite-trondhjemitegranodiorite (TTG) and sanukitoid: relationships and some implications for crustal evolution, Lithos, 79, 1-24, 2005.

McCall, G. J. H.: The geotectonic history o the Makran and adjacent area of Southern Iran, J. Asian Earth Sci., 15, 517-531, 1997.

Mengel, F. and Rivers, T.: Decompression relations and P-T conditions in high-grade rocks, Northern Labrador: P-T-t paths from individual samples and implications for Early Proterozoic tectonic evolution, J. Petrol., 32, 139-167, 1991.

Newton, R. C. and Perkins, D.: Thermodynamic calibration of geobarometers on the assemblage garnet-plagioclase-orthopyroxene (clinopyroxene)-quartz, Am. Mineral., 67, 203-222, 1982.

Niu, Y. L. and O'Hara, M. J.: MORB mantle hosts the missing Eu
( $\mathrm{Sr}, \mathrm{Nb}, \mathrm{Ta}$ and $\mathrm{Ti}$ ) in the continental crust: new perspectives on crustal growth, crust-mantle differentiation and chemical structure of oceanic upper mantle, Lithos, 112, 1-17, 2009.

O'Brien, P. J.: Garnet zoning and reaction textures in overprinted eclogites, Bohemian Massif, European Variscides: a record of their thermal history during exhumation, Lithos, 41, 119-133, 1997.

O’Brien, P. J. and Rötzler, J.: High-pressure granulites: Formation, Recovery of Peak Conditions and Implication for Tectonics, J. Metamorph. Geol., 21, 3-20, 2003.

Okudaira, T. and Yoshitake, Y.: Thermal consequences of the formation of a slab window beneath the Mid-Cretaceous southwest Japan arc: A 2-D numerical analysis, Isl. Arc, 13, 520-532, 2004.

Page, F. Z., Essene, E. J., and Mukasa, S. B.: Prograde and retrograde history of eclogites from the Eastern Blue Ridge, North Carolina, USA, J. Metamorph. Geol., 21, 685-698, 2003.

Pattison, D. R. M.: Petrogenetic significance of orthopyroxene - free garnet + clinopyroxene + plagioclase \pm quartz-bearing metabasites with respect to amphibolite and granulite facies, J. Metamorph. Geol., 21, 21-34, 2003.

Peacock, S. M.: Creation and preservation of subduction-related inverted metamorphic gradients, J. Geophys. Res., 92, 763-781, 1987.

Peacock, S. M.: Thermal and petrologic structure of subduction zones, in: subduction top to bottom, Geophysics Monography, 21, 21-34, 1996.

Peacock, S. M. and Wang, K.: Seismic consequences of warm versus cool subduction zone metamorphism: examples from northeast and southwest Japan, Science, 286, 937-939, 1999.

Peacock, S. M., Rushmer, T., and Thompson, A. B.: Partial melting of subducting oceanic crust, Earth Planet. Sc. Lett., 121, 227244, 1994.

Peacock, S. M., van Keken, P. E., Holloway, S. D., Hacker, B. R., Abers, G., and Fergason, R. L.: structure of the Costa RicaNicaragua subduction zone: slab metamorphism, seismicity and arc magmatism, Phys. Earth Planet. Int., 149, 187-200, 2005.

Pearce, J.: Geochemical fingerprinting of oceanic basalts with applications to ophiolite classification and the search for Archean oceanic crust, Lithos, 100, 14-48, doi:10.1016/j.lithos.2007.06.016, 2008.

Pearce, J. A. and Cann, J. R.: Tectonic setting of basic volcanic rocks determined using trace element analyses, Planet. Sc. Lett., 19, 290-300, 1973.

Perkins III, D. and Newton, R. C.: Charnockite geobarometers based on coexisting ganet-pyroxene-plagioclase-quartz, Nature, 292, 144-146, 1981.

Powell, R. and Holland, T.: Optimal geothermometry and geobarometry, Am. Mineral., 79, 120-133, 1994.

Powell, R. and Holland, T. J. B.: On thermobarometry, J. Metamorph. Geol., 26, 155-179, 2008.

Rapp, R. P., Watson, E. B., and Miller, C. F.: Partial melting of amphibolite/eclogite and the origin of Archean trondhjemites and tonalites, Precambrian Res., 51, 1-25, 1991.

Ricou, L. E.: Tethys reconstructed: plates, continental fragments and their boundaries since $260 \mathrm{Ma}$ from Central America to South-eastern Asia, Geodin. Acta, 7, 169-218, 1994.

Rossetti, F., Nasrabady, M., Vignaroli, G., Theye, T., Gerdes, A., Razavi, S. M. H., and Moin Vaziri, H.: Early Cretaceous 
migmatitic mafic granulites from the Sabzevar range (NE Iran): implications for the closure of the Mesozoic peri-Tethyan oceans in central Iran, Terra Nova, 22, 26-34, 2010.

Sandiford, M.: Low thermal Peclet number intraplate orogeny in central Australia, Earth Planet. Sc. Lett., 201, 309-320, 2002.

Scambelluri, M., Müntener, O., Hermann, J., Piccardo, G. B., and Trommsdorff, V.: Subduction of water into the mantle: history of an Alpine peridotite, Geology, 23, 459-462, 1995.

Sen, C. and Dunn, T.: Dehydration melting of a basaltic composition amphibolite at 1.5 and $2.0 \mathrm{GPa}$ : implications for the origin of adakites, Contrib. Mineral. Petrol., 117, 394-409, 1994.

Sengör, A. M. C., Altmer, D., Cin, A., Ustaömer, T., and Hsü, K. J.: Origin and assembly of the Tethyside orogenic collage at the expense of Gondwana Land, J. Geol. Soc. London, Special Publication, 37, 119-181, 1988.

Shervais, J. W.: Ti-V plots and the petrogenesis of modern and ophiolitic lavas, Earth Planet. Sc. Lett., 59, 101-118, 1982.

Shervais, J. W., Dennis, A. J., McGee, J. J., and Secor, D.: Deep in the Heart of Dixie: Pre-Alleghanian Eclogite and HP Granulite Metamorphism in the Carolina Terrane, South Carolina, USA, J. Metamorph. Geol., 21, 65-80, 2003.

Shojaat, B., Hassanipak, A. A., Mobasher, K., and Ghazi, A. M.: Petrology, geochemistry and tectonics of the Sabzevar ophiolite, North Central Iran, J. Asian Earth Sci., 21, 1053-1067, 2003.

Spear, F. S.: Metamorphic Phase Equilibria and PressureTemperature-Time Paths, Mineralogical Society of America, Washington, DC, USA, 1993.

Spear, F. S. and Kohn, M. J.: Trace element zoning in garnet as a monitor of crustal melting, Geology, 24, 1099-1102, 1996.

Spear, F. S. and Selverstone, J.: Quantitative P-T paths from zoned minerals: theory and tectonic applications, Contr. Mineral. Petrol., 83, 348-357, 1983.

Spray, J. G.: Possible causes and consequences of upper mantle decoupling and ophiolite displacement, in: Ophiolites and Oceanic Lithosphere, edited by: Gass, I. G., Lippard, S. J., and Shelton, A. W., J. Geol. Soc. London, Special Publication, 13, 255-268, 1984.

Stampfli, G. M. and Borel, G. D.: A plate tectonic model for the Paleozoic and Mesozoic constrained by dynamic plate boundaries and restored synthetic oceanic isochrones, Earth Planet. Sc. Lett. 196, 17-33, 2002.

Stern, R. J.: Subduction Zones, Rev. Geophys., 40, 1012, doi:10.1029/2001RG000108, 2002.

Stöcklin, J.: Possible ancient continental margins in Iran, in: The geology of continent margins, edited by: Burke, C. A. and Darke, C. L., Springer, New York, 873-887, 1974.

Sun, S. S. and McDonough, W. F.: Chemical and isotopic systematics of oceanic basalts: implications for mantle composition and processes, in: Magmatism in Ocean Basins, edited by: Saunders, A. D. and Norry, M. J., J. Geol. Soc. London, Special Publication, 42, 312-345, 1989.

Sun, W. D., Bennett, V. C., Eggins, S. M., Arculus, R. J., and Perfit, M. R.: Rhenium systematics in submarine MORB and back-arc basin glasses: laser ablation ICPMS results, Chem. Geol., 196, 259-281, 2003.

Takin, M.: Iranian geology and continental drift in the Middle East, Nature, 235, 147-150, 1972.
Thorkelson, D. J. and Breitsprecher, K.: Partial melting of slab window margins: genesis of adakitic and non-adakitic magmas, Lithos, 79, 25-41, 2005.

Thost, D. E., Hensen, B. J., and Motoyoshi, Y.: Two-stage decompression in garnet-bearing mafic granulits from Sostrene Island, Prydz Bay, East Antarctica, J. Metamorph. Geol., 9, 245-256, 1991.

Tirrul, R., Bell, I. R., Griffis, R. J., and Camp, V. E.: The Sistan Suture Zone of eastern Iran, Geol. Soc. Am. Bull., 94, 134-150, 1983.

Tomkins, H. S., Powell, R., and Ellis, D. J.: The pressure dependence of the zirconium-in-rutile thermometer, J. Metamorph. Geol., 25, 703-713, 2007.

Troitzsch, U. and Ellis, D. J.: Thermodynamic properties and stability of AlF-bearing titanite $\mathrm{CaTiOSiO}_{4}-\mathrm{CaAlFSiO}_{4}$, Contr. Mineral. Petrol., 142, 543-563, 2002.

Tropper, P., Manning, C. E., and Essene, E. J.: The substitution of $\mathrm{Al}$ and $\mathrm{F}$ in titanite at high pressure and temperature: Experimental constraints on phase relations and solid solution properties, J. Petrol., 43, 1787-1814, 2002.

Vielzeuf, D. and Schmidt, M. W.: Melting reactions in hydrous systems revisited: applications to metapelites, metagreywackes and metabasalts, Contr. Mineral. Petrol., 141, 251-267, 2001.

von Huene, R. and Scholl, D. W.: Observations at convergent margins concerning sediment subduction, subduction erosion, and the growth of continental crust, Rev. Geophys., 29, 279-316, 1991.

Wakabayashi, J. and Dilek, Y.: Spatial and temporal relationships between ophiolites and their metamorphic soles: a test of models of forearc ophiolite genesis, in: Ophiolites and Oceanic Crust: New Insight from Field Studies and the Ocean Drilling Program, edited by: Dilek, Y., Moores, E. M., Elthon, D., and Nicolas, A. (Eds.), Geol. S. Am. S., 349, 53-64, 2000.

Watson, E. B., Wark, D. A., and Thomas, J. B.: Crystallisation thermometers for zircon and rutile, Contr. Mineral. Petrol., 151, 413433, 2006

Whitney, D. L. and Evans, B. W.: Abbreviations for names of rockforming minerals, Am. Mineral., 95, 185-187, 2010.

Willard, R. A. and Adams, M. G.: Newly discovered eclogite in the southern Appalachian orogen, Earth Planet. Sc. Lett., 123, 61-70, 1994.

Wilson, J. T.: Did the Atlantic colse and then re-open?, Nature, 211, 676-681, 1966.

Winchester, J. A. and Floyd, P. A.: Geochemical magma type discrimination: application to altered and metamorphosed igneous rocks, Earth Planet. Sc. Lett., 28, 459-469, 1976.

Zack, T., Moraes, R., and Kronz, A.: Temperature dependence of $\mathrm{Zr}$ in rutile : empirical calibration of a rutile thermometer, Contr. Mineral. Petrol., 148, 471-488, 2004.

Zanchi, A., Berra, F., Mattei, M., Ghasemi, M., and Sabouri, J.: Inversion tectonics in Central Alborz, Iran, J. Struct. Geol., 28, 2023-2037, 2006.

Zhao, G., Cawood, P. A., Wilde, S. A., and Liangzhao, L.: Highpressure granulites (retrograded eclogites) from the Hengshan complex, North China Craton: petrology and tectonic implications, J. Petrol., 42, 1141-1170, 2001. 